المجلة الدولية للدراسات التربوية والنفسية e-ISSN 2520-4149 , p-ISSN 2520-4130

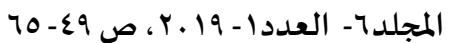
https://doi.org/DOI:10.31559/EPS2019.6.1.4
المجلة الدولية للدراسات
وفاد للدراسات والابحاث

\title{
دراسـة تقويمية لنظام الجودة الداخلية لكلية التربية والآداب بجامعة تبوك
}

\author{
جميلة حمود راشد البلوي \\ الأستاذ المشارك بقسم التربية وعلم النفس- كلية التربية والآداب- المملكة العربية السعودية المعاية \\ drjamela@gmail.com
}

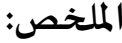

هدفت الدراسة إلى: تعرف أهداف التعليم الجامعي، إضافة إلى الوقوف على أهم التحديات التي تواجه التعليم الجامعي، وكذلك تعرف

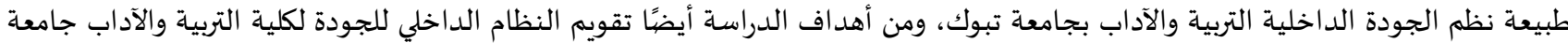

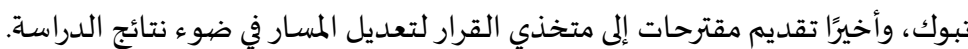
توصلت النتائج إلى :

احتل محور القدرة المؤسسية المرتبة الأولي بينما جاء محور فاعلية التعليم في المرتبة الثانية، لا توجد فروق ذات دلالة إحصائية بين

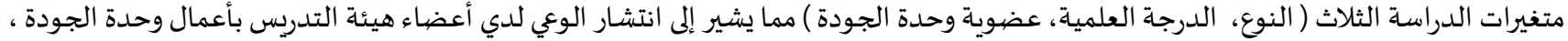

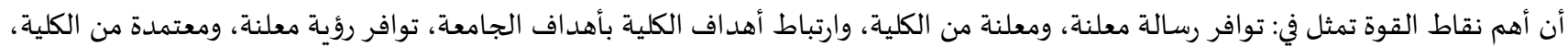
أن أهم نقاط الضعف تمثل في: ضعف خطة التوعية للهوض بخدمة المجتمع وتنمية البيئة، ضعف المشاركة في قوافل التنمية الشاملة.

الكلمات المفتاحية: دراسة تقويمية، نظام الجودة الداخلية.

\section{(c) (1)}

المقدمة:

أصبح التوجاء نحو الجودة في المؤسسات الجامعية ضرورة عصرية، وحتمية تعليمية، وفريضة مستقبلية، حتي تستطيع تلك المؤسسات

التعليمية النظامية وغير النظامية المنافسة الدولية في ظل عصر يموج بالتحديات والتغيرات المتلاحقة عالمياً واقليمياً في شتى مجالات الموات المعرفة . إن مفهوم التنمية البشرية يستخدم دائماً لإدراك حقيقة مفادها أن العنصر الحاسم في التنمية هو الإنسان ، وأن التنمية الحقيقية تنطلق من تنمية

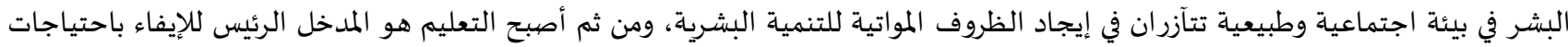

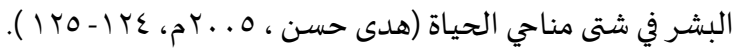

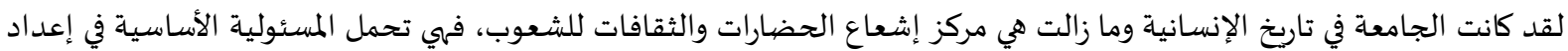
القيادات الفكرية والعلمياة والأدبية والفنية والمهنية بمختلف مستوياتها، والجامعة تشارك مشاركة فاعلة في وضع الخطط لتطوير المجتمع وتنميته، ،

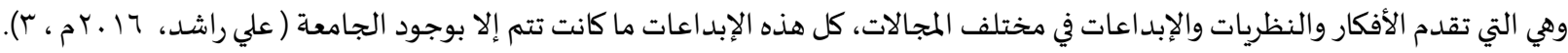
وفي ظل التوسع الكمي للمؤسسات التعليمية؛ والهدف في تكوين كوادر مؤهلة ومعترف بمستوياتها دوليًا من خلال نظرة كلية للمستقبل؛ الأمر الذي الذي يتطلب أن يتطور دور الجامعات بما يقابل التحديات العلمية المعاصرة، وبما يحقق الجودة الشاملة لمخرجات التعليم الجامعي.

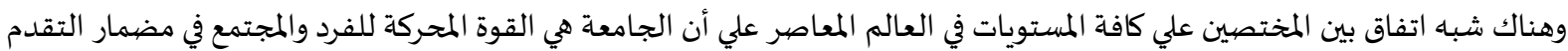
والتنمية الشاملة والمستدامة، وهي مفتاح عبور المجتمعات بوابة حضارة القرن الحادي والعشرين التي تتميز بالتحولات والتحديات العلمية والتكنولوجية المعقدة والمتنامية في مختلف المجالات، وهي البوتقة التي تنصهر فيها عقول الصفوة - طلاباً وأساتذة - لتحقيق طموحات مجتمعاتهم

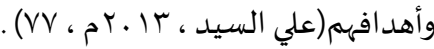
إن الجامعة مؤسسة من نوع خاص قادرة على اختراق الحدود والوصول إلى العالمية لما لها لها من دور في العمل بالعلم وتطبيقه لتحقيق التقدم

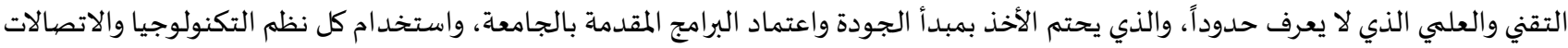

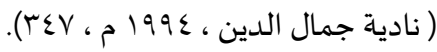
يتضح مما سبق أن الجامعة تمثل معقل الفكر الإنساني ، فهي قاطرة التقدم في المجتمعات، وإن تحقيق متطلبات الجودة بالجامعات صار ضرورة 
علي الرغم من ذلك وفي ظل التحديات العالمية والمحلية تواجه مؤسسات التعليم العالي عددًا من القضايا التي تتعلق بالمنافسة والتميز ؛ مما

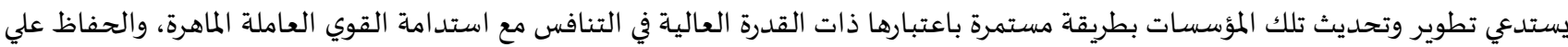

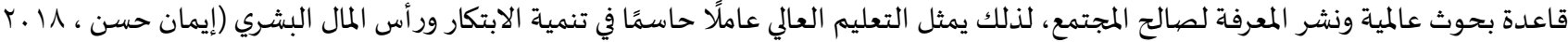
وغدا التغيير وتحقيق التنمية الفعلية لمواجهة متطلبات وتحديات عصر ما بعد الحداثة معتمداً بالدرجة الأولى علي وجود نظام تعليمي قادر م، (). علي إفراز خريج ذي كفاءة وجودة عالية، بحيث يكون قادرًا علي تقديم كافة المعلومات والمهارات والخبرات التعليمية المطلوبة منها تجاه

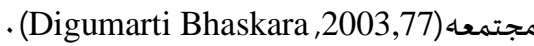

إن نشر ثقافة الجودة في المؤسسات الجامعية يقتضي تنفيذ عدد من البرامج التدربية المتخصصية عن الجودة لكافة عناصر المنظومة

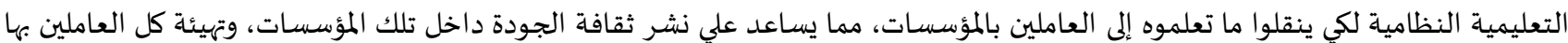

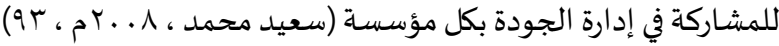

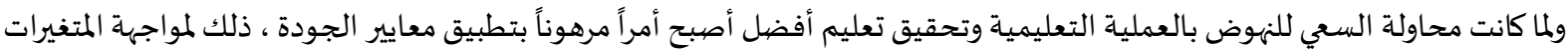

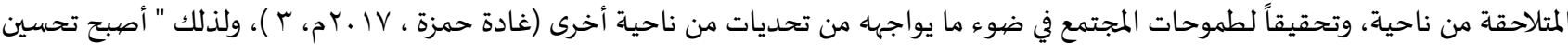

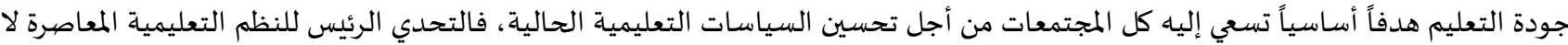

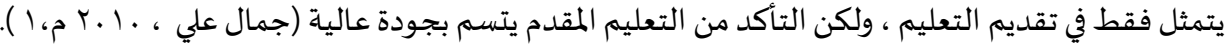

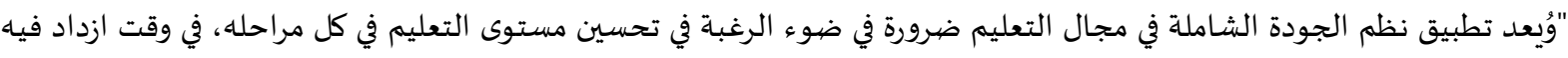
التنافس، ولم يعد التنافس وطنيًا بل أنه في ظل العولمة وما تحمله من تحديات أصبح عالمياً، مما يزيد من صعوبة المنافسة وشدتها "( عزة أخا وآخرون،

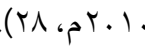

وتتضح المشكلات التي تواجه التعليم الجامعي بوجه عام، والتعليم بجامعة تبوك بوجه خاص والتي يمكن أن نذكر منها على سبيل المثال لا الحصر: غياب وجود رؤية أو استراتيجية مستقبلية محددة لمنظومة التعليم العالي. التشاباه والنمطية في النظم والبرامج والمناهج الدراسية . تراجع دور القيم الجامعية والمعايير الأخلاقية غياب التنوع في هياكل التخصصيات المختلفة في الجامعة ضيعف إمكانات وفرص الأنشطة الثقافية والفنية والرياضية. أصبحت قضية تجويد التعليم العالي ضرورة عصرية إلى الحد الذي جعل المفكرين يطلقون على هذا العصر ( عصر الجودة ) باعتبارها التحدي الحقيقي الذي سيواجـاء الأمم في العقود القادمة . وقد بدأت بعض كليات جامعة تبوك في الحصول على الجودة لبرامجها والاعتماد الأكاديهي، وكليات أخرى في طريقها لنيل الجودة، مما

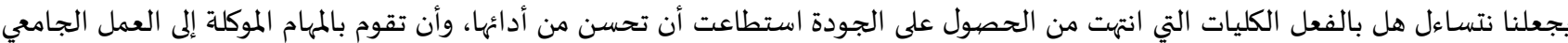
بشكل أفضل، وهذا ما حدا بالباحثة للدراسة التقويمية لنظام الجودة الداخلية لكلية التربية والآداب جامعة تبوك.

مشكلة الدراسة: من خلال نتائج الدراسات السابقة مثل دراسة عزة أغا وأخرون والتي أوصت بضرورة تقويم جهود وحدات الجودة بالكليات للوقوف علي نقاط القوة وتدعيمها ونقاط الضعف وعلاجها؛ من هنا نبعت مشكلة الدراسة، والتي تمثلت تقويم نظام الجودة الداخلي لكلية التربية والآداب في جامعة تبوك لتعرف المردود الذي حققته نظم الجودة الداخلية حتى الآن من خلال تقويم الأداء بها في مجالي: القدرة المؤسسية وما يتعلق بها من معايير تتمثل في( التخطيط الاستراتيجيج- الهيكل التنظيمي- القيادة والحوكمة- الموارد الماليةالمشاركة المجتمعية وتنمية البيئة- تقويم الأداء الكلى للمؤسسة). الفاعلية التعليمية وما يتعلق بها من معايير تتمثل في ( الطلاب والخريجين - والمعايير الأكاديمية- والبرامج التعليمية والمقررات الدراسية-والتعليم والتعلم - وأعضاء هيئة التدريس- -والبحث العلمي - وطلاب الدراسات العليا ).

$$
\text { نبعت أهمية الدراسة من: }
$$




$$
\text { تقد تقديد المعوقات التي واجهت مشروعات إنشاء وحدات الجودة الداخلية لكلية التربية والآداب جامعة تبوك. }
$$

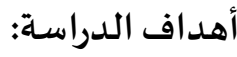

$$
\begin{aligned}
& \text { 1. تعرف أهداف التعليم الجامعي. }
\end{aligned}
$$

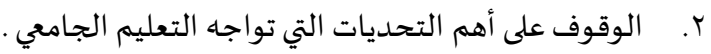

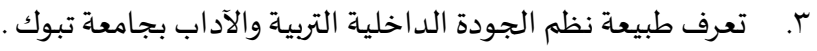

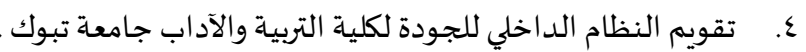

$$
\begin{aligned}
& \text { 0. تقديم مقترحات إلى متخذي القرار لتعديل المسار في ضوء نتائج الدراسـة . } \\
& \text { تسـاؤلات الدراسـة : } \\
& \text { ا. ما أهم أهداف التعليم الجامعي بالمملكة العربية السعودية ؟ }
\end{aligned}
$$

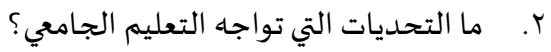

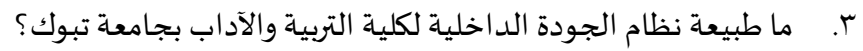

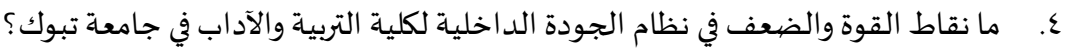

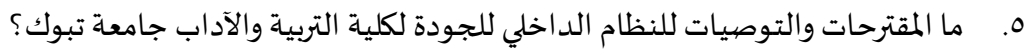

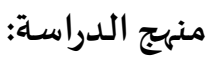

استخدمت الدراسة المنهج الوصفي بغرض جمع المعلومات ، حيث يهدف المنهج إلى وصف ما هو كائن من ظواهر أو أحداث معينة بعد جمع

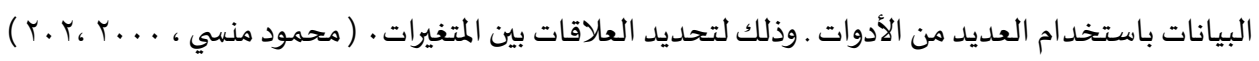

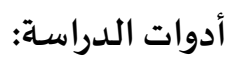

تم تصميم استبانة مكونة من محورين أساسيين وهما : القدرة المؤسسية ويحتوي علي :

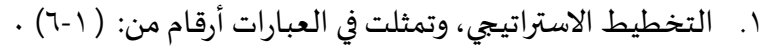

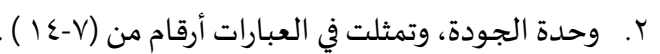

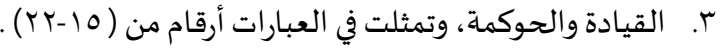

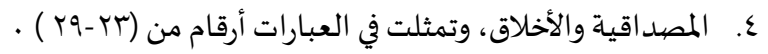

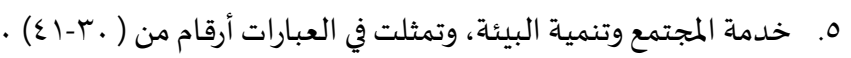

$$
\text { والمحور الثاني : فاعلية التعليم ويحتوي علي: }
$$

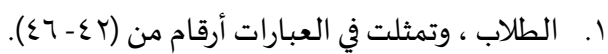

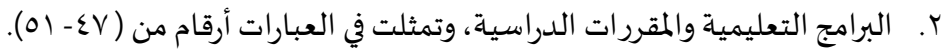

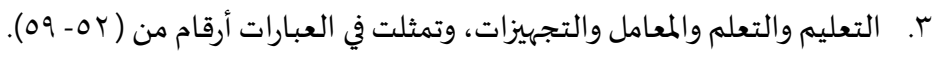

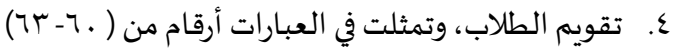

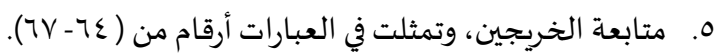

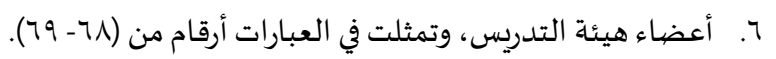

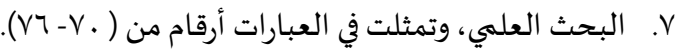

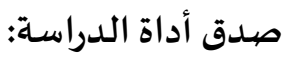

ويقصد باه أن تقيس الاستبانة ما أعدت لقياساه، وللتأكد من صدق الاستبانة وثباته من حيث ملاءمته لأهداف الدراسـة قامت الباحثة

باتباع الخطوات الإجرائية التالية : 
صدق المحكمين:

وذلك لمعرفة مدى صدق الاستبيان من حيث المحتوى، مدى سلامة صياغة الجمل، كذلك مدى تغطيتها لجوانب المشكلة، وأسئلة الدراسـة، ومدى ملاءمة العبارات للموضوع الذي تعبر عنه، وقد قامت الباحثة بعرض الاستبانة علي عدد من المحكمين من أساتذة التربية، وخبراء الجودة، وبعد المداث

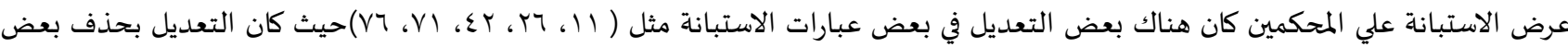
الكلمات واضيافة البعض.

ثبات الاستبانة :

قامت الباحثة بتطبيق ألفـا كرونباخ لقياس الاستبانة ككل ، وكان معامل الثبات ( 91 (9) وهـو معامل عـال من الثبات يعول عليـه ، كما تم

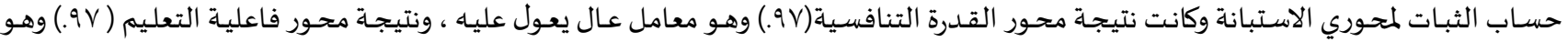

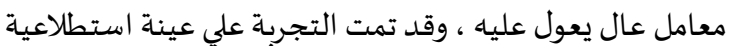

حدود الدراسة وعينتها: اقتصرت الدراسة الحالية علي أعضاء هيئة التدريس بكلية التربية والآداب - جامعة تبوك ، تم اختيار العينة بطريقة عشوائية من بين

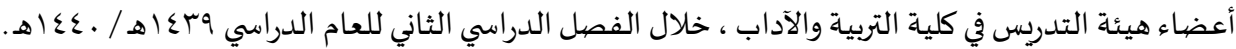

عينة الدراسـة:

اعتمدت الدراسة على عينة ممثلة لكلية التربية والآداب جامعة تبوك ، وكذلك عينة من أعضاء هيئة التدريس بالجامعة ؛ وذلك لتحقيق

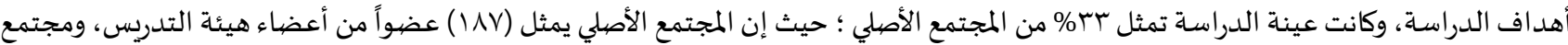

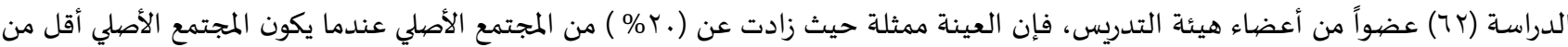

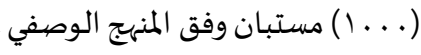

جدول(1): وصف عينة الدراسة

\begin{tabular}{|c|c|c|c|c|c|c|c|c|}
\hline \multicolumn{2}{|c|}{ عضيوفي وحدة الجودة } & \multicolumn{3}{|c|}{ الدرجة العلمية } & \multicolumn{2}{|c|}{ النوع } & \multirow[t]{2}{*}{ العينة } & \multirow[t]{2}{*}{ م } \\
\hline لا & نعم & أستاذ & أستاذ مشارك & أستاذ مساعد & إناث & ذكور & & \\
\hline$\varepsilon_{0}$ & IV & r & rq & ri & rq & $\pi$ & كلية التربية والآداب & \\
\hline Tr & - & Tr & - & - & Tr & - & الجملة & \\
\hline
\end{tabular}

المعالجة الإحصيائية :

قامت الباحثة بتفريخ الاستبانة الخاصة بالدراسة التي تم الحصول عليها بصورة مجملة للعينة، وكذلك مع متغيرات الدراسة ، وتم

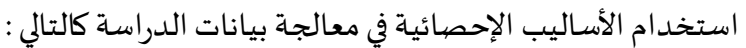
استخدمت الباحثة المتوسط الحسابي والانحراف المعياري لمعرفة إلى أي مدي تتوافر البنود في كل من محوري الدراسة. استخدمت الباحث المتوسطات الحسابية والانحرافات المعيارية لترتيب العبارات حسب أهميتها داخل المحاور . استخدمت الباحثة اختبار (ت) لحساب فروق المتوسطات ودلالتها الإحصائية لمتغيري النوع ، وعضوية وحدة الجودة . استخدمت الباحثة (ANOVA) لحساب الفروق لمتوسطات متغير الدرجة العلمية.

مصطلحات الدراسـة :

الجودة: منهج عمل شامل ومستمر يقوم علي جهد جماعي بروح الفريق ، يشمل كافة الأنشطة والتي يتم تقديمهما إلى سوق العمل ، وكذلك

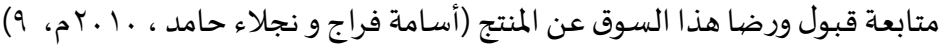

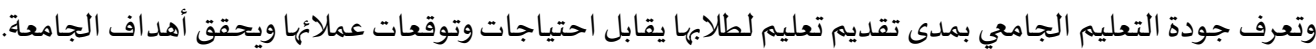
التقويم: عملية جمع وتصنيف وتحليل وتفسير بيانات أو معلومات كمية أو كيفية عن ظاهرة أو عمل أو موقف أو سلوك ؛ بقصد استخدامها في

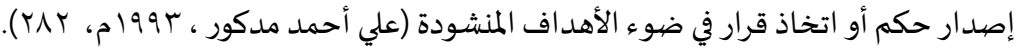


ويري ( أسامة عبد الغفار ، ـ ـ ام، ^) أن التقويم عملية جمع وتصنيف وتحليل وتفسير بيانات أو معلومات كمية أو كيفية لظاهرة ما بهدف

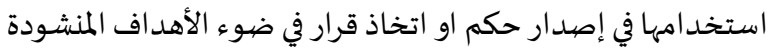

مما سبق يمكن القول بأن التقويم في هذه الدراسـة يعني إصدار حكم علي مدى تحقق الأهداف ، ووضع الأيدي على نقاط القوة وتدعيمها ، ووضع الأيدي علي نقاط الضعف وعلاجها .

$$
\text { الدراسـات السـابقة: }
$$

شملت الدراسة الحالية علي العديد من الدراسـات المتعلقة بمتغيرات الدراسة والتي تم ترتيبها زمنياً كالتالي :

دراسـة تطبيق مبادئ إدارة الجودة الشـاملة لتحسين أداء كلية خدمة المجتمع والتعليم المستمربجـامعة أم القري (خالد زقزوق، ومصطفي

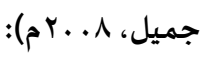

هدفت الدراسة إلى تعرف استخدام مبادئ إدارة الجودة الشاملة ل( Deming ) في البرامج والدورات التي تقدمها كلية خدمة المجتمع

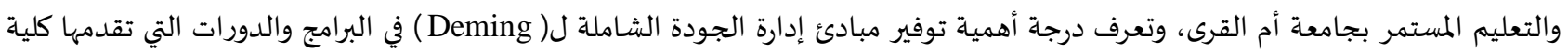
خدمة المجتمع والتعليم المستمر بجامعة أم القري . وتوصلت الدراسة إلى نتائج أهمها ( أن درجة استخدام مبادئ إدارة الجودة الشاملة ل( Deming) في البرامج والدورات التي تقدمها كلية

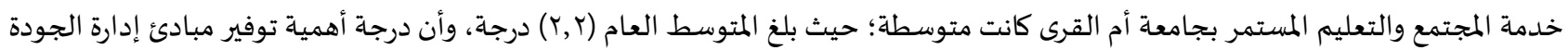
الشاملة ل ( Deming) في البرامج والدورات التي تقدمها كلية خدمة المجتمع والتعليم المستمر كانت عالية حيث بلغ المتوسط (r,Or) درجة .

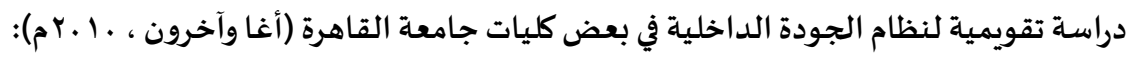
هدفت الدراسة إلى تعرف أهداف وسمات التعليم الجامعي ، وكذلك تعرف نظم الجودة بالتعليم العالي، إضافة إلى تقويم النظام الداخلي

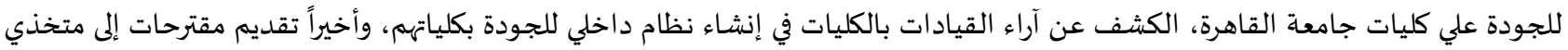

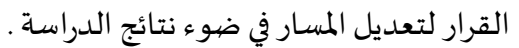
أسفرت النتائج عن نسبة تحقق معايير القدرة المؤسسية على التوالي تمثلت في التخطيط الاستراتيجي ، وحدة الجودة، القيادة والحوكمة ،

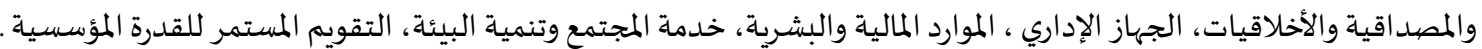
وأن نسبة تحقق معايير الفاعلية التعليمية لأعضاء هيئة التدريس تمثلت في الطلاب ثم البرامج، والتعليم والتعلم، تقويم الطلاب، متابعة

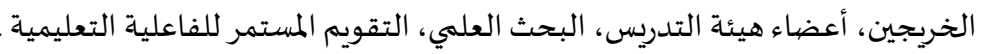

دراسـة و اقع مركز التدريب وخدمة المججتمع بجامعة الدمام في ضيوء معايير الجودة الشاملة (علي بن عبد الله العيد ، بrع اهـ): هدفت الدراسة إلى دراسـة واقع أداء مركز التدريب وخدمة المجتمع بجامعة الدمام في ضوء معايير الجودة الشاملة من وجهة نظر أعضاء هيئة التدردس والمتدربين . كشفت النتائج عن ممارسة جميع مؤشرات الأداء في الجودة بمركز التدريب وخدمة المجتمع بجامعة الدمام بدرجة مرتفعة، وذلك من وجهي نظر أعضاء هيئة التدريس والمتدربين في ضوء معايير الجودة التالية ( معيار إنجاز المتدربين، معيار فاعلية التعليم والتدريب، معيار تلبية البرامج التدرببية لاحتياجات المتدربين وسوق العمل، معيار فاعلية الإدارة في رفع مستوي الإنجاز للمتدربين ، معيار دعم المتدربين وإرشادهم، معيار قدرة المؤسسة علي تحسين جودة التعليم، معيار فاعلية أداء مركز التدريب في تقديم الخدمات لأفراد المجتمع المحلي وتأهيلهه، معيار فاعلية أداء مركز التدريب في تقديم خدمات الاستشارات لخدمة المجتمع .

دراسة تشخيصية لمشكلات التقويم بالجامعة ووضع تصيور للتطوير (نادية محمود شريف وأخرون ،ع ا. r م):

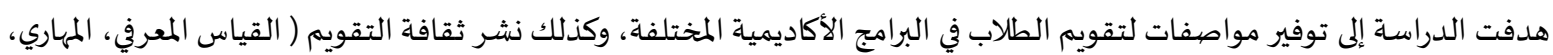
الوجداني )، إضافة لتعرف مشكلات التقويم بالجامعة، وأخيراً الوصول إلى الاحتياجات التدريبية اللازمة لأعضياء هيئة التدريس . أظهرت النتائج ضعف الممارسات للتقويم بصفة عامة فلم توجد نسب اتفاق عالية تؤكد علي الالتزام بمبادئ استمرارية التقويم ، ضرورئية

التحول من قياس المعرفة الاستذكار إلى تقويم إثرائي ، والتحول إلى قياس قدرة الطالب على توظيف المعرفة التي اكتسبها ، ونقلها إلى مواقف حياة. دراسة وزارة التعليم التشيكية ( Nenadal,2015) :

هدفت الدراسة إلى جمع المعلومات الأساسية التي تتعلق بمشروع ضمان جودة التعليم العالي التشيكية وتقييمها ، كما هدفت إلى تطوير منهج لتقييم الجودة بشكل شامل. 


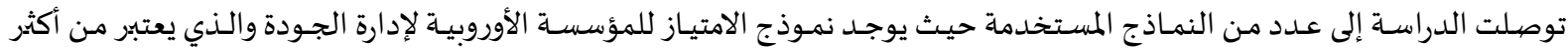

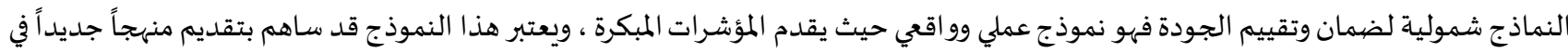
تطوير مؤسسات التعليم العالي التشيكية . : دراسة غانا (Tsevi,2015) :

هدفت الدراسة إلى البحث عن كيفية تنفيذ التدابير اللازمة لضمان الجودة في التعليم العالي الخاص بغانا ، كما تبحث عن التدابير

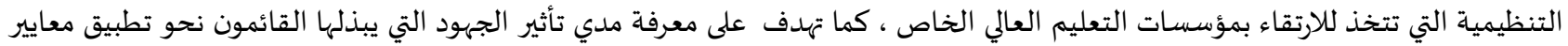
ضيمان الجودة والاعتماد في غانا . توصلت الدراسة إلى تأييد المتخصصيين في التعليم العالي لوضع سياسات تهدف للتصديدي لمشكلات التعليم العالي والتي أهمها العجز في

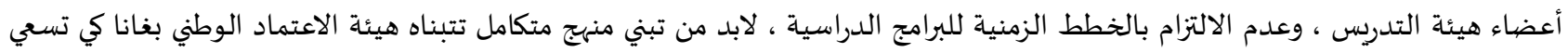

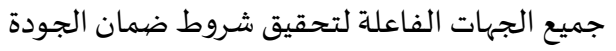

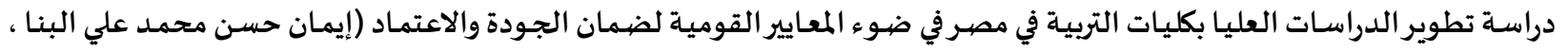

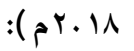

هدفت الدراسة إلى تعرف الإطار الفكري لبرامج الدراسات العليا بكليات التربية ، وكذلك توضيح الأسس الفكرية والفلسفية لضمان جانسان جودة

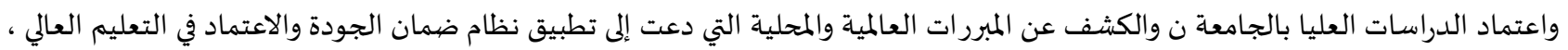

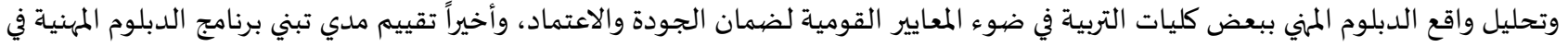
التربية المعايير القومية لضمان الجودة والاعتماد.

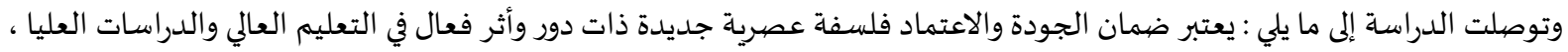

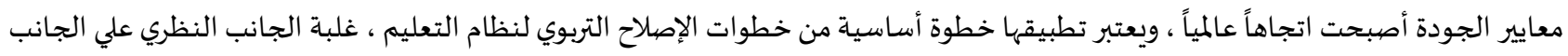

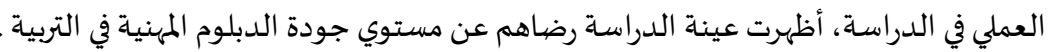

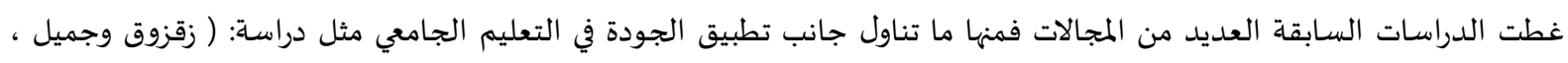

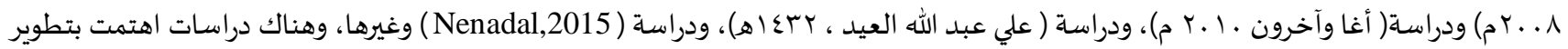

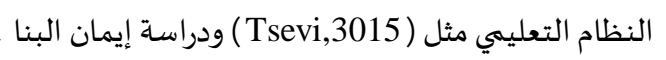

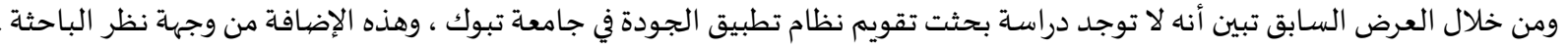

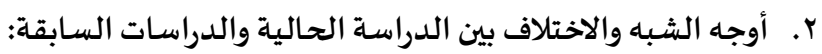

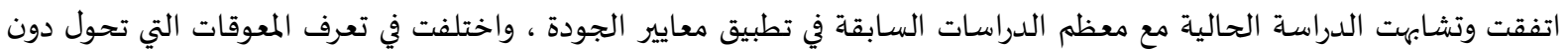

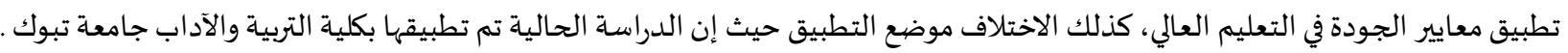

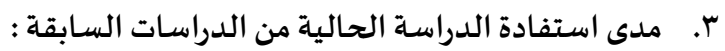
استفادت الدراسة الحالية من الدراسات السابقة في إطارها النظري وبناء الأدواتئ : الدات، وتفسيرالنتائج. خطة السيرفي الدراسة : لتحقيق الهدف الأول والذي نص على تعرف أهداف التعليم الجامعي تناولت الباحثة ذلك من خلال الإطار النظري للدراسة، ولتحقيق

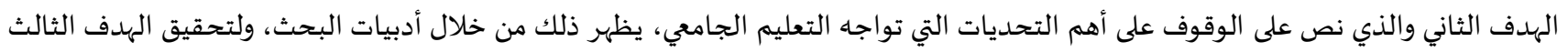

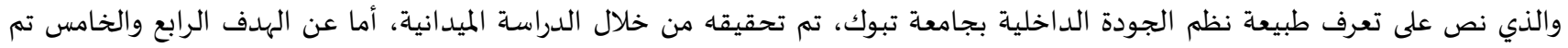
تحقيقهما من خلال نتائج الدراسة النظرية والميدانية

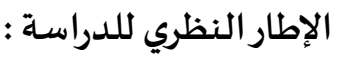

لقد تأكدت أهمية العلم والمعرفة في حياة البشر ، كما أن الثروة الحقيقة تكمن في الاستثمار في هؤلاء البشر ؛ حيث يصبحون أمة عالمة المبة بدلاً

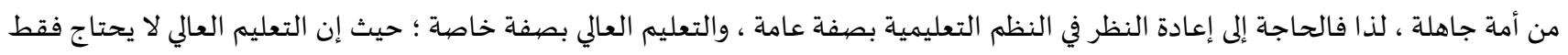


إلى تعديل وتطوير، بل إن فلسفته وسياساته ووسائطه ومناهجه كل هذا لابد من تعديل وتطوير عن طريق تفعيل نظام ضمان الجودة والاعتماد بالكليات لذا يمكن إلقاء الضيوء علي ما يلي :

ا ـ أهداف التعليم العالي: تعتبر البدايات الأولي للجامعة المعاصرة وُجد في الجامعات الأوروبية حيث النشاط الدراسي المنتظم بشكل عام منذ حوالى القرن الثاني عشر الميلادي ، وكان التدفق العلمي في القرن السادس عشر، ومن هنا قامت الجامعات بنقل الحقيقة الثابتة، وكشف حقيقة الظواهر الطبيعية

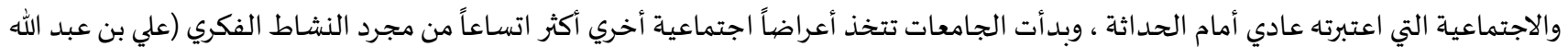

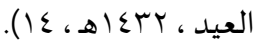

ويعتبر التعليم العالي - في نطاق السياسة التربوية الشـاملة- من الأدوات الأساسية التي تسهم في تكوين الفرد والمجتمع ، وبلورة ملامحها في الحاضر والمستقبل معاً ، وضمان طرق التطور السليم للأمة في مسيرتها نحو أهدافها في التقدم والرقي في مختلف الميادين حيث يعتبر التعليم العالي

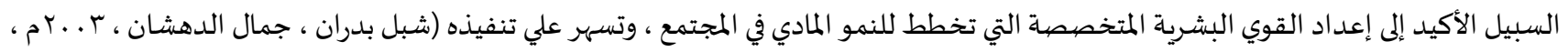

وتكمن أهداف التعليم الجامعي في : أ- تلبية الاحتياجات الحالية والمستقبلية للتنمية المجتمعية وسئوق العملية العمل والإنتاج.

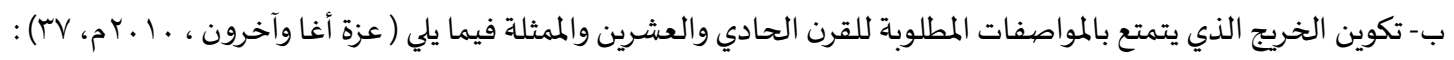
تنمية مهارات التعلم الذاتي المستمر . الإعد اد المتكامل علمياً ، وتقنياً ، وفكرياً ، وثقافياً. القدرة علي توظيف البحث العلمي ، وتنمية القدرات العلمية . تنمية مهارات الاتصال الفعال . تأكيد الثقة بالنفس ، والتحلي بالقدرات التنافسية . القدرة علي التفكير النقدي وحل المشكلات. الحفاظ علي الهوية الثقافية واللغة القومية . مراعاة الأخلاقيات المهنية والعلمياة . r. أهم التحديات التي تواجه التعليم الجامعي: إن تطوير التعليم الجامعي لم يعد مجرد اختيار وإنما أصبح ضرورة تفرضها متغيرات الحاضر والمستقبل ، فهو في حاجة مستمرة للتطوير ، ولكن يقف أمام التطوير جملة من التحديات أهمها : التدفق المعرفي:

إن العصر الحالي يعرف بعصر المعلومات والمعارف تمييزاً له عن عصر الصناعة أو الزراعة ، وهو بالضرورة يغير من طبيعة المعلومات والمعرفة والعلم وطرق التعامل معها، والوصهول إليها ووظيفتها وعمرها ( محمد نبيل نوفل ، 7 . . T م ، 7V). وُيعد النمو المعرفي بمثابة الفوضات للأعداد الوفيرة للدوريات العلمية في جميع المجالات المعرفية والتخصصيات ووفيات العلمية الدقيقة، والكم

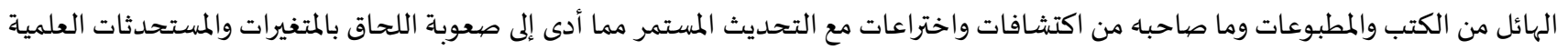

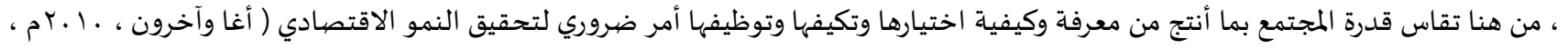

وفي عصر ما بعد الحداثة لم تعد المعرفة ترفًا فلابد وأن تكون متعددة الأوجه، فليس هناك طريقة واحدة للمعرفة؛ بل هناك طرقاً متعددة

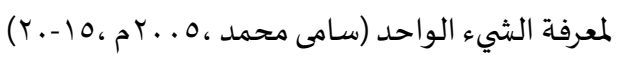

وترتب على ثورة المعرفة أن صارت المعرفة تجارة لها عائدها ومردودها العالي المتزايد أكثر من الإنتاج المادي المتمثل في الأجهزة والمعدات التي نستخدمها، فتزايد المعارف يتطلب الارتفاع المستمر بقدرات الإنسان ومهاراته، وتجعله دائما يبحث عن الجديد في تخصصياه، ويسعى لتحقيق تنميته

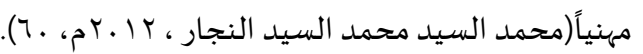
يتضح مما سبق أن تزايد المعارف والعلوم حدا لا مثيل لله مما يفرض علي الجامعات ضهرورة تطور أساليبها في ضوء تلك التحديات لتساير التغيرات المتلاحقة وفق معايير الجودة والاعتماد. 


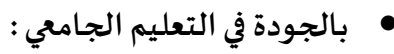

يُعرف معهد الجودة الأمريكي الجودة بأها تأدية العمل الصحيح علي النحو الصحيح من أول مرة، أما مفهوم الجودة في التعليم فهو عملية

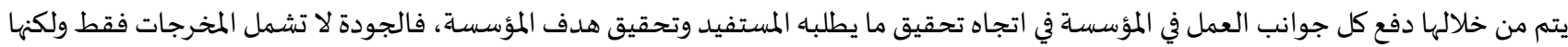
تأخذ في الاعتبار كل التفاعلات من مختلف عناصر المنظمة من مدخلات وعمليات ومخرجات، فالجودة مجهودات القيادة في بناء منظومة أساسها

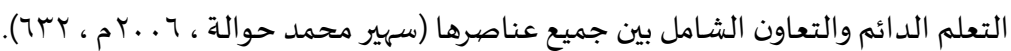
ولما كانت محاولة السعي للنهوض بالعملية التعليمية وتحقيق تعليم أفضل أصبح أمراً مرهوناً بتطبيق معايير الجودة، وذلك وذلك لمواجهة

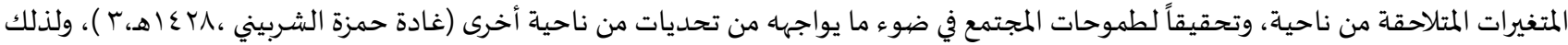

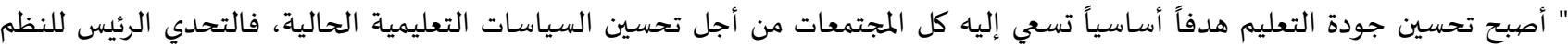

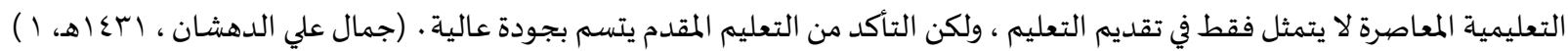
إن مفهوم الجودة وفقاً لما تم الاتفاق عليه في مؤتمر اليونسكو للتعليم والذي أقيم في باريس في اكتوبر (1991م)، ينص علي أن الجودة في

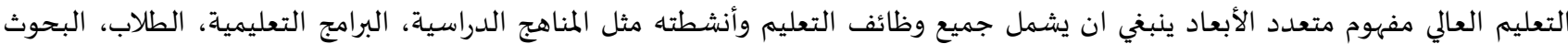

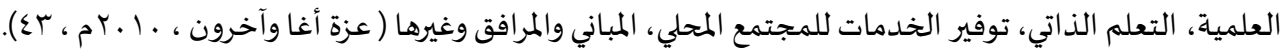

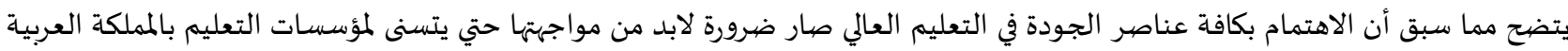
السعودية السير نحو تحقيق متطلبات الجودة والاعتماد.

\section{r. مساعي المملكة العربية السعودية لتحقيق الجودة في التعليم العالي :} تم تصميم نظام الاعتماد وتوكيد الجودة في السعودية وذلك للتأكيد من جودة التعليم العالي حتي يساير المستويات العالمية ويعترف بهائا بشكل واسع في المجتمعات الأكاديمية والتخصصية العالمية، ووضع الخطط للتأكد من مستويات تحصيل تعليم الطلاب بغض النظر عن المؤسسة

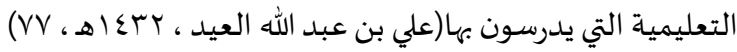
وتعرف الهيئة الوطنية للتقويم والاعتماد الأكاديمي الجودة بأها مستوي الأداء مقارنة بالمعايير المقبولة للممارسات الجيدة عالمياً والخاصة

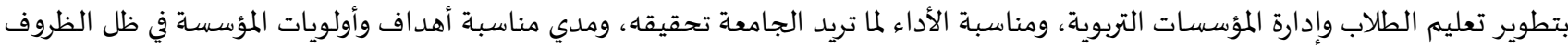

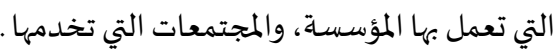
واشتقت معايير الاعتماد من الممارسات المقبولة التي رأتها الهيئة من خلال الإطار المحلي، وتمثل أفضل الممارسات العالمية، ويستخدمها

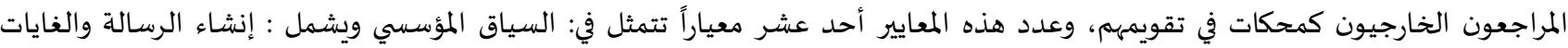
والأهد اف ، والسياسة والإدارة ، وإدارة عمليات توكيد الجودة وتحسينها وجودة التدريس والتعلم وتشمل: التعلم والتدريس، ودعم تعلم الطلاب، وتوفير

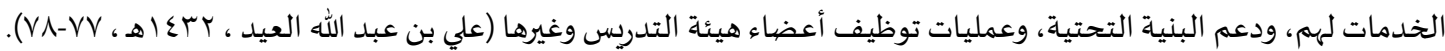
يتضح مما سبق أن المملكة العربية السعودية قد خطت خطوات واسعة في تطبيق معايير الاعتماد وتوكيد الجودة، وهذا ما تسعي إليها

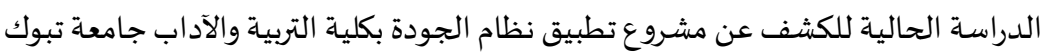

\section{تفسير نتائج الدراسـة الميدانية :}

أولاً : لمعرفة أي المحاور أكثر تفعيلاً للجودة لدى عينة أعضاء هيئة التدريس، إضافة إلى مدي فاعلية الوحدة داخل كلية التربية والآداب، قامت الباحثة بترتيب المحاور مع إجمالي الاستبانة ككل وفق ما يلى:

\begin{tabular}{|c|c|c|c|c|c|}
\hline الترتيب & الانحراف المعياري & المتوسط الحسابي & عدد العبارات & المحور & م \\
\hline الأول &., , & $r, r r$ & \&1 & محور القدرة المؤسسية & 1 \\
\hline الثاني & $\cdot, \varepsilon \varepsilon$ & $r, 1 \Lambda$ & ro & محور فاعلية التعليم & r \\
\hline- & . & 5,19 & $\mathrm{VI}$ & إجمالي الاستبانة & $r$ \\
\hline
\end{tabular}

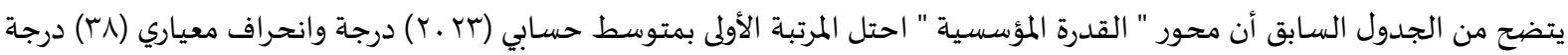

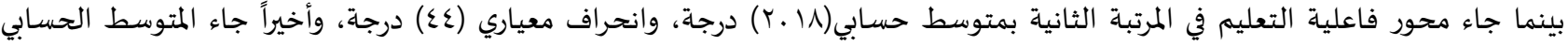

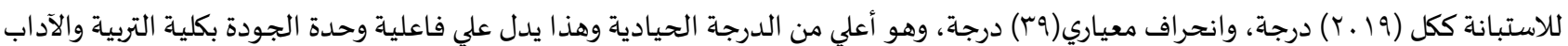

جامعة تبوك. 
ثانياً : يتم استخدام الإرباع الأعلى والأدنى لكل محور حسب المتوسط الحسابي باعتبار الأعلى نقاط القوة والأدنى نقاط الضعف لنصل إلى التقويم ؛ وذلك لتدعيم نقاط القوة وعلاج نقاط الضعف : ا. ترتيب العبارات للإباع الأعلى في محور القدرة المؤسسية حسب درجة أهميتها من وجهة نظر أعضياء هيئة التدردس: المحور الأول : القدرة المؤسسية: أ- الإرباع الأعلى للمحور الأول :

خصصت الباحثة إحدى وأربعين عبارة تناولت محور القدرة المؤسسية ، وأخضعها للأوزان النسبية لإيجاد المتوسط الحسابي والانحراف

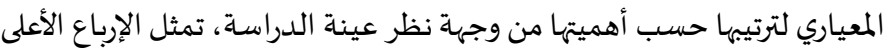
مصدر قوة فيما يلي :

جدول (ץ): رأي عينة المعلمين في القدرة المؤسسية ( الإبرباع الأعلى للمحور)

\begin{tabular}{|c|c|c|c|c|}
\hline الترتيب & الانحراف المعياري & المتوسط الحسابي & 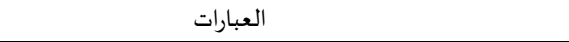 & م \\
\hline الأول &., 11 & $r, 97$ & توافر رسالة معلنة ومعتمدة للكلية & 1 \\
\hline 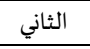 & . ro & r,qr & ارتباط أهداف الكلية بأهداف الجامعة & $r$ \\
\hline 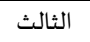 & . I & T,QT & توافر رؤية معلنة ومعتمدة للكلية & $r$ \\
\hline 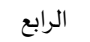 & 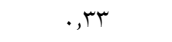 & $r, 91$ & ارتباط الخطة الاستراتيجية بأهداف الكلية & $\varepsilon$ \\
\hline 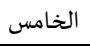 & . & r,q. & توافر أهداف استراتيجية للكلية & 0 \\
\hline 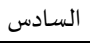 & . זr & $r, \wedge 9$ & 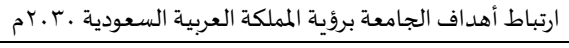 & 1 \\
\hline 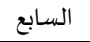 & $\cdot, 7 \varepsilon$ & $r, \varepsilon_{0}$ & إجراء تقويم مستمر للكلية & $\checkmark$ \\
\hline 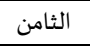 &., 07 & $r, \varepsilon r$ & الوعي بثقافة الجودة & $\wedge$ \\
\hline 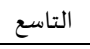 & $\cdot, \mathrm{V})$ & $r, \varepsilon r$ & التفاعل مع أقسام الكلية & 9 \\
\hline العاشر &.,$\leqslant 9$ & $r, \varepsilon$. & الانتقال من خبرة الماضي إلى المستقبل & 1. \\
\hline الأول & $.4 \Lambda$ & t.rt & إجمالي المحور ككل & \\
\hline
\end{tabular}

لاحظ من الجدول السـابق ما يلي :

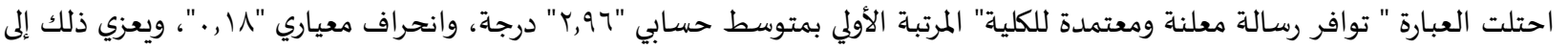

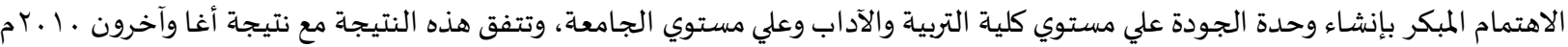
والتي أكدت علي أن التخطيط الاستراتيجي والذي انبثق منه توافر رسالة معلنة ومعتمدة، وهذا يؤكد علي القدرة المؤسسية لكلية التربية والآداب

بجامعة تبوك . جاءت العبارة " ارتباط أهداف الكلية بأهداف الجامعة " في المرتبة الثانية بمتوسط حسابي "بو,ץ" درجة ، وانحراف معياري "هץ , ."، ويعزي ذلك إلى أن الأهداف الاستراتيجية للكلية اشتقت من رؤية ورسالة الكلية والتي انبثقت من أهداف الجامعة ، وتتفق هذه الاجراءات مع نتيجة دراسة

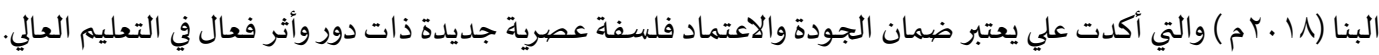

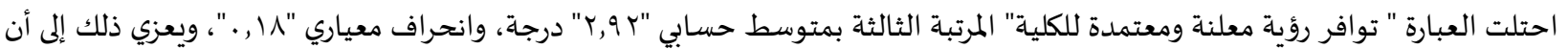
رؤية الكلية كانت واضحة منذ البداية، وكانت بمثابة الحلم للمؤسسة وتمثلت في أن تكون وحدة الجودة المرجعية الأساسية لكل أقسام الكلية

الأكاديمية والإدارية . جاءت العبارة " ارتباط الخطة الاستراتيجية بأهداف الكلية" في المرتبة الرابعة بمتوسط حسابي " او,ץ" درجة ، وانحراف معياري "سז, ."، ويعزي ذلك إلى أن الجامعة ما تزال في مرحلة التكوين، وأن جل اهتمامها هو وضع خطة استراتيجية طموحة . احتلت العبارة " توافر أهداف استراتيجية للكلية" المرتبة الخامسة بمتوسط حسابي " .9,ج" درجة ، وانحراف معياري "سم, . "، ويعزي ذلك إلى أن الأهداف مرتبطة ومنبثقة من الخطة الاستراتيجية؛ وذلك لأن تحقيق الأهداف سيؤدي بالضرورة إلى تحقيق الخطة الاستراتيجية، وتتفق هذه

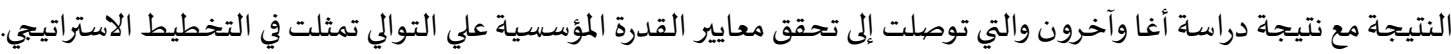

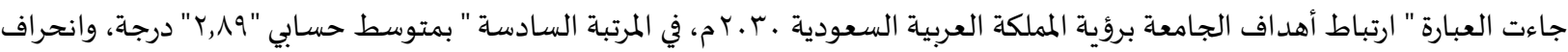
معياري "rr, ."، ويعزي ذلك إلى أن جامعة تبوك من الجامعات حديثة النشأة ومن الطبيعي أن ترتبط وفق رؤية المملكة العربية السعودية . احتلت العبارة " إجراء تقويم مستمر للكلية " المرتبة السابعة بمتوسط حسابي "هـ,؟" درجة، وانحراف معياري "§؟7, ."، ويعزي ذلك إلى أن إجراء التقويم جزء رئيس وأساسي لأي مؤسسة تعليمية تربوية للوقوف علي نقاط القوة وتدعيمها ونقاط الضعف وعلاجها. 


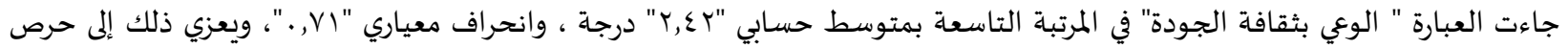

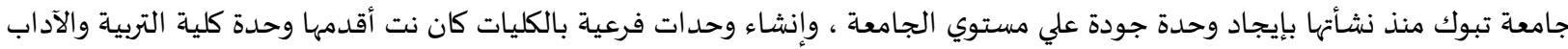

مما ساعد علي نشر ثقافة الجودة .

احتلت العبارة " الانتقال من خبرة الماضي إلى المستقبل" المرتبة العاشرة بمتوسط حسابي ".ع,؟" درجة ، وانحراف معياري "و؟؛, ."، ويعزي ذلك إلى استفادة المسئولين بوحدة الجودة بكلية التربية والآداب من تجارب السابقين وتعدئ المباديل مسار الوحدة إلى المستقبل الأفضل .

جدول(ع): رأي عينة المعلمين في القدرة المؤسسية ( الإرباع الأدنى للمحور )

\begin{tabular}{|c|c|c|c|c|}
\hline 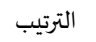 & الانحراف المعياري & المتوسط الحسابي & 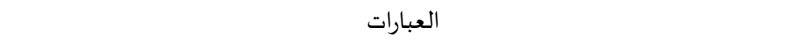 & م \\
\hline الأول & $\cdot, \wedge$ & 1,97 & توافر أساليب لأفراد المجتمع للاستفادة من أنشطة الكلية. & 1 \\
\hline الثاني & $\cdot, \mathrm{Vr}$ & 1,90 & تطوير الخدمات الإدارية بالكلية . & r \\
\hline 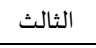 &., 71 & $1,9 \varepsilon$ & يوجد خربطة زمنية لتنمية الموارد البشربة بالكلية . & $r$ \\
\hline 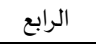 & . & $1,9 \pi$ & ربط المكافآت بمستوي الإنجاز لكل العاملين بالكلية. & $\varepsilon$ \\
\hline 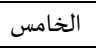 &., $1 \varepsilon$ & 1,9 . & توافر خطة لتنمية الموارد البشرية بالكلية . & $\circ$ \\
\hline 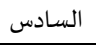 & $\cdot, \mathrm{V} \varepsilon$ & 1,19 & توافر إجراءات مناسبة للحفاظ علي حقوق النشر . & 7 \\
\hline 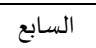 &.,$\varepsilon \wedge$ & $1, \lambda$ & اختيار القيادات المناسبة في أماكنها المناسبة . . & v \\
\hline 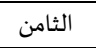 &., 7 . & $1, \wedge$. & توافر معايير لاختيار القيادات (رؤساء الأقسام - الوحدات ذات الطابع الخاص - الوكلاء). & $\wedge$ \\
\hline التاسع & $\cdot, \wedge$ & $1, \mathrm{v9}$ & تشارك الكلية في قوافل تنمية شاملة للمجتمع . & 9 \\
\hline العاشر & $\cdot, \sqrt{ })$ & $1, \mathrm{r}$ & توجد خطة لتوعية أفراد الكلية بتنمية البيئة . & 1. \\
\hline 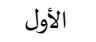 &.$r$ & t. r & 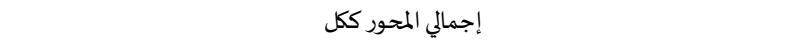 & \\
\hline
\end{tabular}

يتضح من الجدول السابق ما يلي :

جاءت العبارة " توافر أساليب لأفراد المجتمع للاستفادة من أنشطة الكلية " في المرتبة الأولي في الإباع الأدنى والذي يمثل نقاط ضيعف بمتوسط

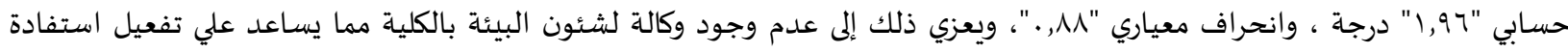

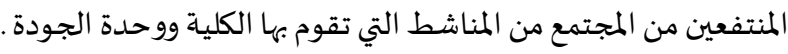

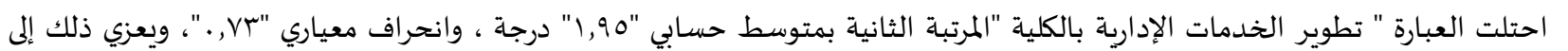

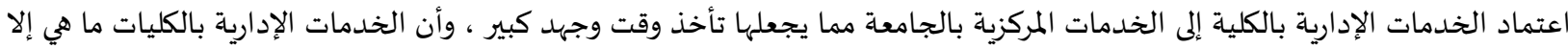

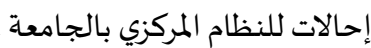

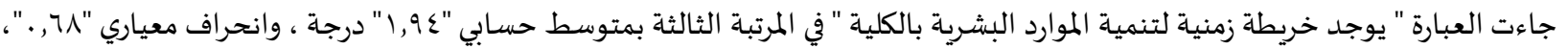
ويعزي ذلك إلى تنمية الموارد البشرية بالجامعة حيث يعتمد علي النظام المركزي بالجامعة مما يضعف وجود خطط وخرائط زمنية تنبع من الكليات وفق احتياجاتها . احتلت العبارة " ربط المكافآت بمستوي الإنجاز لكل العاملين بالكلية" المرتبة الرابعة بمتوسط حسابي "سوه, ا" درجة وانحراف معياري " بآ, . "

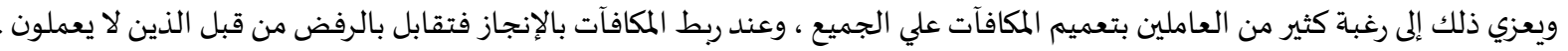

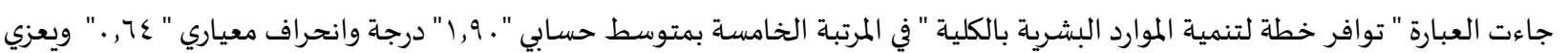

ذلك إلى النمط المركزي لتنمية الموارد البشرية ، وقليل ما تعقد كلية بعينها من خلال وحدة الجودة دورة تدريبية لتنمية الموارد البشرية فيها. احتلت العبارة " توافر إجراءات مناسبة للحفاظ علي حقوق النشر" المرتبة السادسة بمتوسط حسابي "ح/, ا" درجة وانحراف معياري " عV, . "

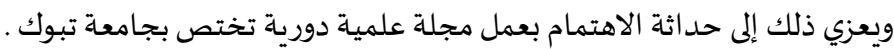

جاءت العبارة " اختيار القيادات المناسبة في أماكنها المناسبة" في المرتبة السابعة بمتوسط حسابي "AN, ا" درجة وانحراف معياري " دع, . " ويعزي ذلك إلى الجامعة في بدايتها اعتمدت علي الكثير من الوافدين ، إضافة إلى ندرة أعضاء هيئة التدريس من الوطنيين فكان تولي المناصب لمن يمتلك

الدرجاة العلمية .

هاحتلت العبارة " توافر معايير لاختيار القيادات ( رؤساء الأقسام - الوحدات ذات الطابع الخاص - الوكلاء ) المرتبة الثامنة بمتوسط حسابي

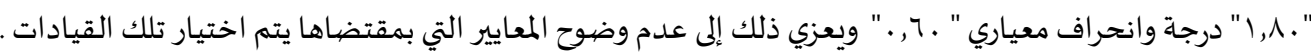

جاءت العبارة " تشارك الكلية في قوافل تنمية شاملة للمجتمع" في المرتبة التاسعة بمتوسط حسابي "V9,I" درجة وانحراف معياري " .ـر, ." ويعزي ذلك إلى عدم تفعيل منصبب وكيل للجامعة والكليات المتعلق بشئون خدمة المجتمع وتنمية البيئة . 
احتلت العبارة " توجد خطة لتوعية أفراد الكلية بتنمية البيئة" المرتبة العاشرة بمتوسط حسابي ". V, I" درجة وانحراف معياري " الV, . " ويعزي ذلك إلى تداخل بعض مهام الوكلاء مع بعض إضافة إلى ضعف تفعيل دور وحدة الجودة في جانب تنمية المجتمع .

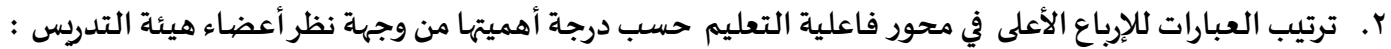

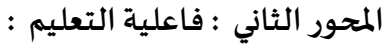

أ- الإرباع الأعلى للمحور فاعلية : فاعليها لتعليم :

خصصت الباحثة خمس وثلاثين عبارة تناولت محور فاعلية التعليم ، وأخضعها للأوزان النسبية لإيجاد المتوسط الحسابي والانحراف

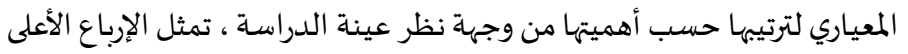
مصدر قوة فيما يلي :

جدول (0): رأي عينة المعلمين في فاعلية التعليم ( الإرباع الأعلى للمحور)

\begin{tabular}{|c|c|c|c|c|}
\hline الترتيب & الانحراف الممعياري & المتوسط الحسابي & 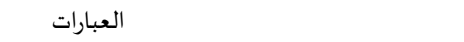 & م \\
\hline 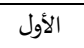 &., 01 & $r, 17$ & توجد مواصفات للورقة الاختبارية & 1 \\
\hline 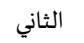 &., 09 & $r, 07$ & تصميم البرامج التعليمية وفق المعايير الأكاديمية & r \\
\hline 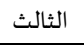 &., 07 & $r, 0 \varepsilon$ & تتنوع أساليب التقويم بالكلية & $r$ \\
\hline 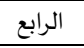 &., 07 & r,or & تصميم البرامج وفق أهدافها & $\varepsilon$ \\
\hline 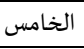 &., 79 & r,o. & توجد إلية لتقويم أداء أعضاء هيئة التدريس & 0 \\
\hline 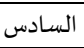 & . & $r, \varepsilon r$ & توافر إرشاد أكاديمي للطلاب & 1 \\
\hline 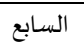 &., 77 & $r, \varepsilon$. & توافر إلية مستمرة للتقويم بالكلية & v \\
\hline 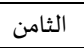 &., 77 & T,rV & اطلاع أعضاء هيئة التدريس علي نتائج التقويم & $\wedge$ \\
\hline 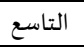 & $\cdot, 71$ & $r, 47$ & وجود لجنة ممتحنين لكل برنامج & 9 \\
\hline 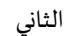 &.$\varepsilon \varepsilon$ & $r .11$ & إجمالي المحور ككل & \\
\hline
\end{tabular}

يتضح من الجدول السـابق ما يلي :

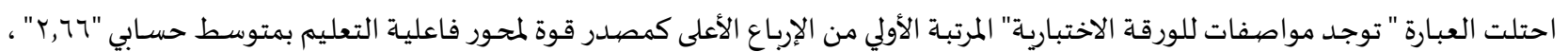

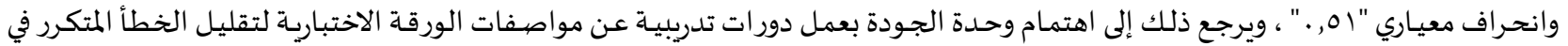

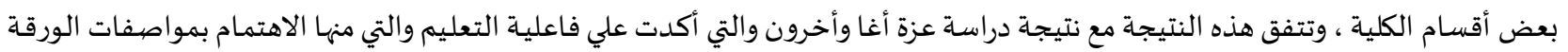

الاختبارية.

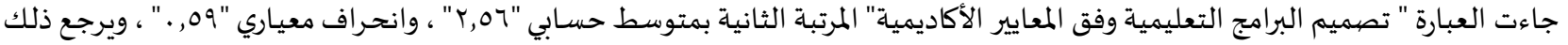

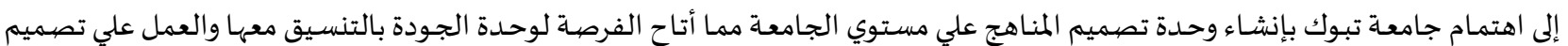
البرامج وفق المعايير الأكاديمياة .

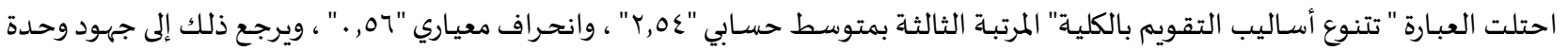

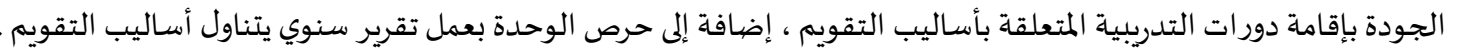

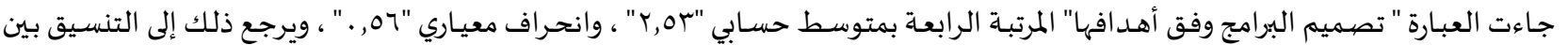

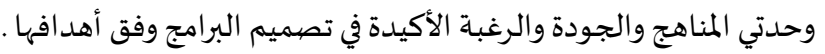

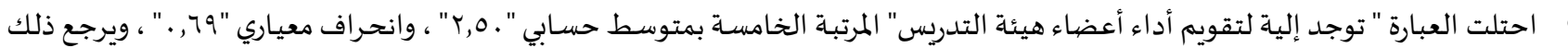

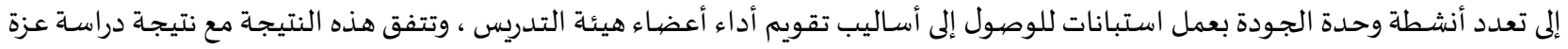
أغاوآخرون. جـاءت العبـارة " توافر إرشـاد أكاديمي للطلاب " في المرتبـة السـادسـة بمتوسط حسـابي "بع,؟" ، وانحـراف معيـاري "rا7, . " ، ويرجع ذلك إلى تطبيق نظام الساعات المعتمدة بالكلية والجامعة مما يقتضي وجود مرشد أكاديمي لمتابعة المعدل التراكمي ومتابعة الطلاب .

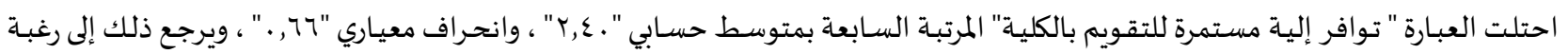
الجامعة والكلية في الدخول في سباق مع الجامعات الكبيرة بالمملكة وتعرف نقاط القوة والضعف من خلال اليات التقويم.

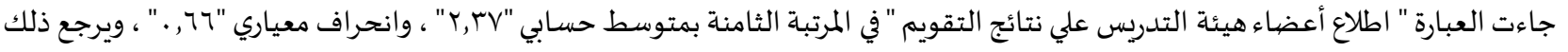
إلى جهود وحدة الجودة وذلك بإحاطة أعضاء هيئة التدريس بنتائج التقويم لتعديل المسار . 
احتلت العبارة " وجود لجناة ممتحنين لكل برنامج" المرتبة التاسعة بمتوسط حسابي "حץ,ץ" ، وانحراف معياري "خا, . " ، ويرجع ذلك إلى أن هذا من متطلبات تطبيق نظام الساعات المعتمدة المطبقة بالكلية ب- الإبرباع الأدنى للمحور فاعلية التعليم:

جدول (7): رأي عينة المعلمين في فاعلية التعليم ( الإرباع الأدنى للمحور)

\begin{tabular}{|c|c|c|c|c|}
\hline 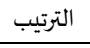 & الانحراف المعياري & المتوسط الحسابي & | ل العبارات & ? \\
\hline 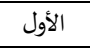 &., 77 & I,AV & توافر معامل وأجهزة تخدم العملية التعليمية. & 1 \\
\hline 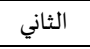 & $\cdot, \mathrm{Vr}$ & I,Nr & توجد صيانة دورية للمعامل والأجهزة. & r \\
\hline 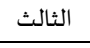 & זוד & 1,11 & ت توافر نظام لمعرفة نظام رضا الخريجين. & r \\
\hline 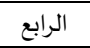 & . & $1, \lambda$. & توافر نظام لمتابعة الخربجين. & $\varepsilon$ \\
\hline 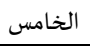 & $\cdot, 71$ & $1, \mathrm{vV}$ & توافر ملتقي لتوظيف الخربجين. & $\circ$ \\
\hline 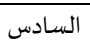 & $\cdot, \mathrm{Vr}$ & $1,0 \mathrm{~V}$ & يوجد نظام لجذب الوافدين بالكلية. & 7 \\
\hline 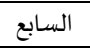 & $\cdot, \mathrm{VI}$ & 1,07 & توجد إلية للاستفادة من نتائج الأبحاث العلمية. & $\mathrm{V}$ \\
\hline 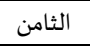 &., 79 & $1,0 \varepsilon$ & توافر بحوث بينية مشتركة بين الأقسام العلمية بالكلية . & $\wedge$ \\
\hline 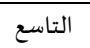 &.,$V T$ & $1,0 \mathrm{r}$ & يوجد نظام لجذب الطلاب الفائقين محلياً وإقليمياً وعالمياً. & $q$ \\
\hline الثاني &.$\varepsilon \varepsilon$ & $r .11$ & إجمالي المحور ككل & \\
\hline
\end{tabular}

يتضمن الجدول السابق ما يلي :

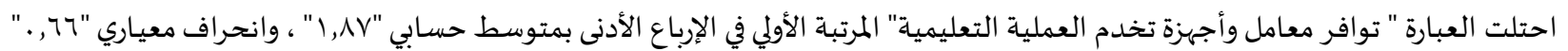

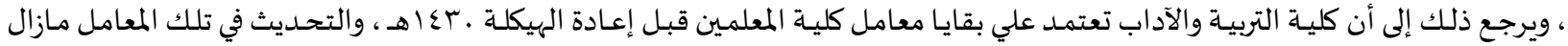

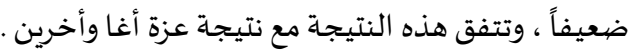

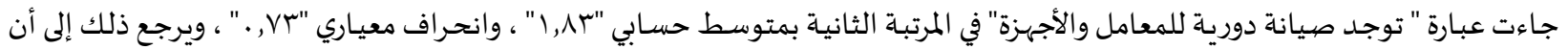
محاولة التحديث موجودة ولكن حسب الميزانيات المرصودة وفق متطلبات الجامعات الناشئة .

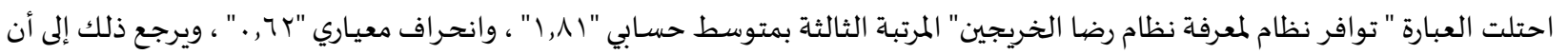
من ضمن محاور الجودة الاطلاع علي وجود أنظمة لرضيا الخريجين ومتابعتهم في سوق العمل . جاءت العبارة " توافر نظام لمتابعة الخريجين" في المرتبة الرابعة بمتوسط حسابي ". ^, ا" ، وانحراف معياري "با7, ." ، ويرجع ذلك إلى أن متابعة

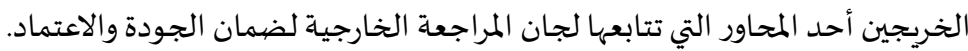

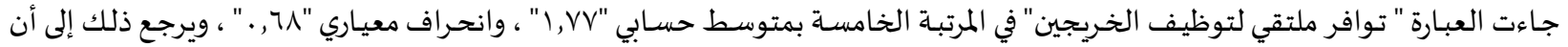
ندرة عمل ملتقيات لمتابعة وتوظيف الخريجين .

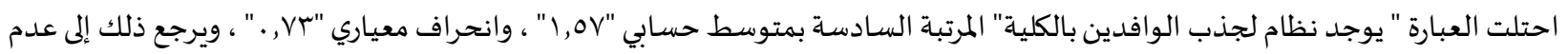
تفعيل نظام الوافدين مثل الجامعات الكبيرة بالمملكة العربية السعودية .

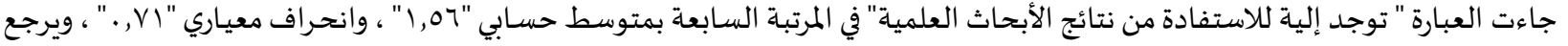

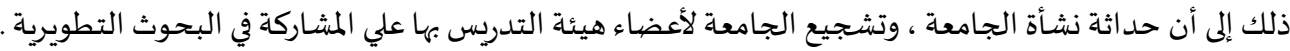

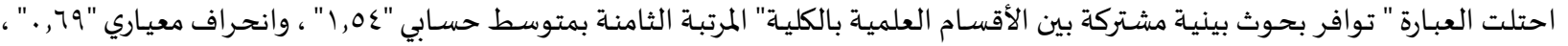

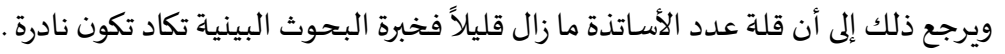
جاءت العبارة " يوجد نظام لجذب الطلاب الفائقين محلياً وإقليمياً وعالمياً" المرتبة التاسعة والأخيرة بمتوسط حسـابي "به ه 1" ، وانحراف معياري

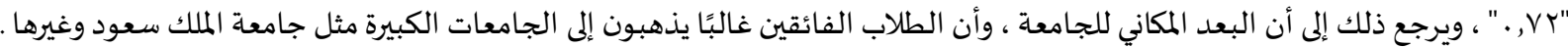

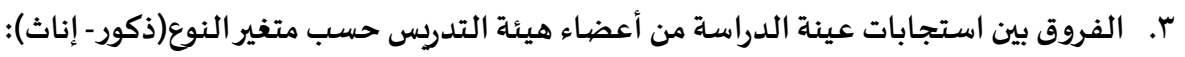
أظهرت نتائج الدراسة أناه لا يوجد فروق ذات دلالة إحصائية بين استجابات عينة الدراسة وفق متغير النوع، والجدول التالي يوضح ذلك. 


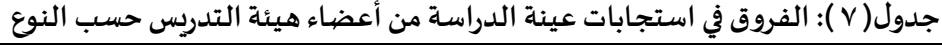

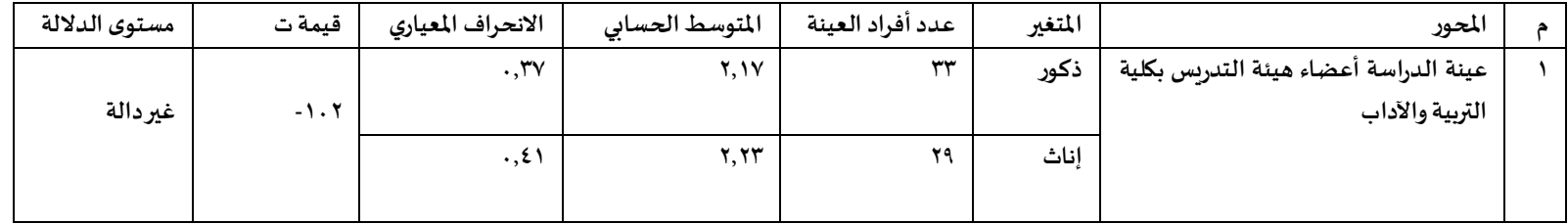

يتضح من الجدول السابق أنها :

• لا توجد فروق ذات دلالة إحصيائية حسب متفير النوع بين أعضاء هيئة التدريس حول تقويم أداء وحدة الجودة وفق أهدافها ، وهذا يشير إلى أن هناك توافق حول أراء عينة الدراسة ، وفي ضوء هذه النتيجة يمكن القول بأن هناك وعى بعمل وحدة الجودة .

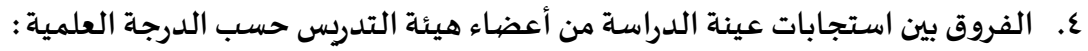
أظهرت نتائج الدراسة أنه لا يوجد فروق ذاندات أتينه دلالة إحصائية بين استجابات عينة الدراسة وفق متفير الدرجة العلمية، والجدول التالي يوضح ذلك .

\begin{tabular}{|c|c|c|c|c|c|c|c|}
\hline مستوى الدلالة & قيمة ت & الانحراف المعياري & المتوسط الحسابي & عدد أفراد العينة & 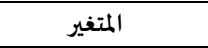 & المحور & م \\
\hline \multirow[t]{2}{*}{ غير دالة } & \multirow[t]{2}{*}{ r,07 } &.,$r 1$ & $r, .9$ & $r_{1}$ & أستاذ مسـاعد & \multirow[t]{2}{*}{ التدينة الدراسة أعضاء هيئة } & 1 \\
\hline & &., Vo & $r, r)$ & r & أستاذ مشارك وأستاذ & & \\
\hline
\end{tabular}

يتضح من الجدول السابق أنها :

• ل الوجد فروق ذات دلالة إحصائية حسب متغير الدرجة العلمية بين أعضياء هيئة التدريس حول تقويم أداءوحدة الجودة وفق أهدافها ، وهذا يشير إلى أن هناك توافق حول أراء عينة الدراسـة ، وفي ضوء هذه النتيجة يمكن القول بأن هناك انصهار وتبادل خبرات بين الدرجات العلمية . .

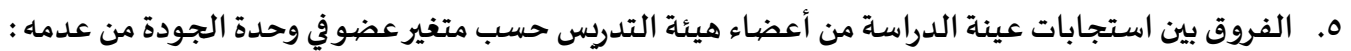

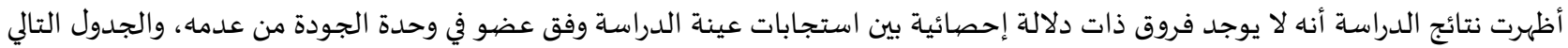
يوضح ذلك.

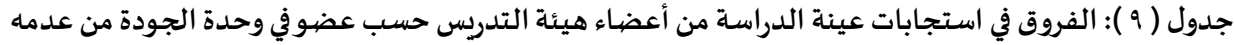

\begin{tabular}{|c|c|c|c|c|c|c|c|}
\hline مستوى الدلالة & قيمة ت & الانحراف المعياري & المتوسط الحسابي & عدد أفراد العينة & المتغير & \multirow{2}{*}{\multicolumn{2}{|c|}{ م 1 المحور الدراسة أعضاء هيئة }} \\
\hline & & ,,$\varepsilon$ & $r, r \Lambda$ & IV & عضيو في وحدة الجودة & & \\
\hline 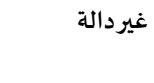 & $r, \varepsilon \varepsilon$ & ( & $r, I T$ & so & ليس عضواً في وحدة & التدريس بكلية التربية والآداب & \\
\hline
\end{tabular}

يتضح من الجدول السابق أنها :

• • لا توجد فروق ذات دلالة إحصيائية حسب متغير عضوية وحدة الجودة من عدمها بين أعضياء هيئة التدريس حول تقويم أداء وحدة الجودة وفق أهدافها ، وهذا يشير إلى أن هناك توافق حول أراء عينة الدراسة ، وفي ضوهو هذه النتيجة يمكن القول بأن هناك وعي بعمل وحدة الجودة

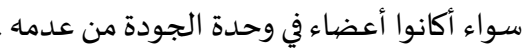

$$
\text { أولاً : ملخص لأهم النتائج : }
$$

ا. أن من بين أهداف التعليم الجامعي تكوين الخريج الذي يتمتع بمهارئ التهارات القرن الحادي والعشرين والتي منها : تنمية مهارات التعلم المستمر،

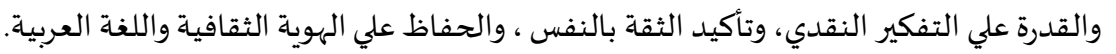

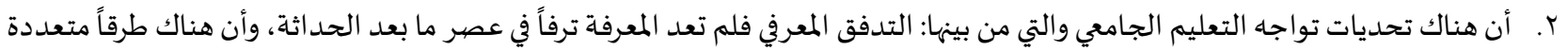
لمعرفة الشيء، وأن المعرفة لها عائدها ومردودها العالي، إضافة إلى ضرورة توافر الجودة في التعليم والتي لا تهتم بالمخرجات فحسب بل تعمل علي كل المراحل. كا. أن للمملكة العربية السعودية مساعي لتحقيق الجود في التعليم العالي ؛ حيث وضعت معايير للممارسات الجيدة . 
ثانياً : نتائج الدراسة الميدانية :

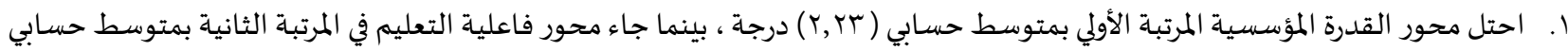

$$
\text { ( }(Y, \mid \Lambda)
$$

r. لا توجد فروق ذات دلالة إحصائية بين متغيرات الدراسة الثلاث ( النوع ، الدرجة العلمية ، عضوية وحدة الجودة ) مما يشير إلى انتشار الوعي

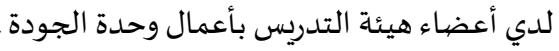

r. أن أهم نقاط القوة في محور القدرة المؤسسية تمثل في : توافر رسالة معلنة ، ومعلنة من الكلية ، وارتباط أهداف الكلية بأهداف الجامعةة،

$$
\text { توافر رؤياة معلنة ، ومعتمدة من الكلية. }
$$

ع. أن أهم نقاط القوة في محور فاعلية التعليم تمثل في : توجد مواصفات للورقة الاختبارية ،تصميم البرامج التعليمية وفق المعايير الأكاديمية،

$$
\text { تنوع أساليب التقويم. }
$$

0 أ أن أهم نقاط الضعف في محور القدرة المؤسسية تمثل في : ضعف خطة التوعية للنهوض بخدمة المجتمع وتنمية البيئة ، ضعف المشاركة في

قوافل التنمية الشـاملة.

7. أن أهم نقاط الضعف في محور فاعلية التعليم تمثل في : ضعف جذب الطلاب الفائقين محلياً وإقليمياً، قلة توافر البحوث البينية بين أقسام

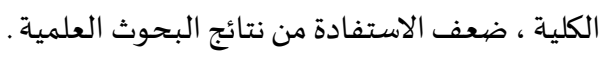

ثالثاً : توصيات الدراسـة :

توطئة:

ا. تؤكد الاتجاهات الحديثة علي ضرورة الوصهول إلى منظومة تعليمية لتحقيق الجودة الشاملة للوصول إلى مخرجات ذات جودة عالية.

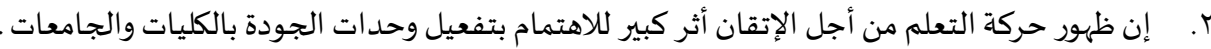

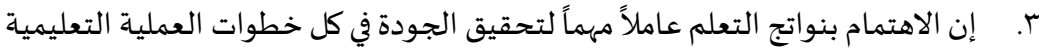

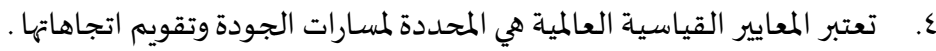
توصيات الدراسة :

حرصت الدراسة الحالية علي تقديم توصيات إجرائية قابلة للتطبيق نبعت من نقاط الضعف في نتائج الدراسة والتي من أهمها :

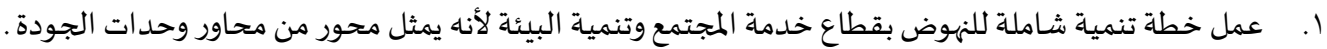

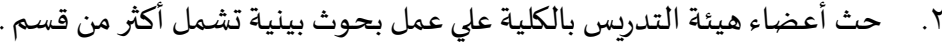

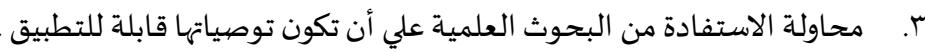

ع. تبني أهداف تربوية واضحة ورؤي مستقبلية لوحدة الجودة بالكلية

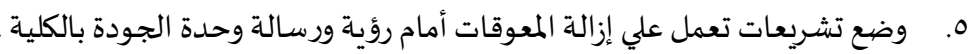

بحوث مقترحة:

تؤمن الدراسة الحالية البحث العلمي من حيث ينتهي الآخر ، لذا تقترح ما يلي من دراسات :

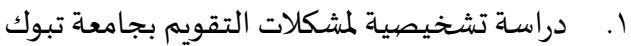
r. إجراء دراسة تقويمية لوحدة الجودة علي مستوي جامعة تبوك .

المراجع:

أولاً: المراجع العربية:

ا. . أخا، عزة وآخرون، (. (Y) دراسة تقويمية لنظام الجودة الداخلية في بعض كليات جامعة القاهرة ، جامعة القاهرة.

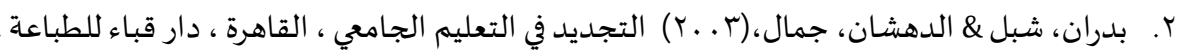

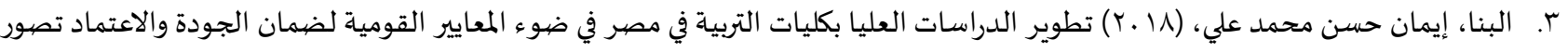
مقترح ، رسالة ماجستير غير منشورة ، جامعة بنها ، كلية التربية .

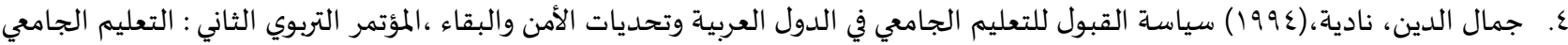

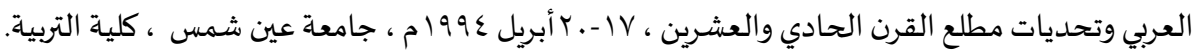

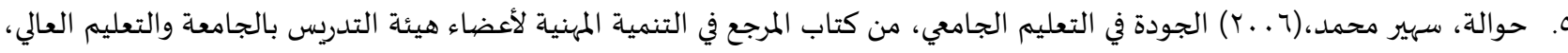

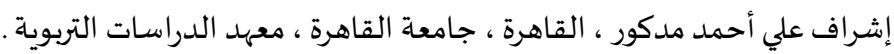


7. الدهشان، جمال علي،(ابعاهـ) مشكلات ومعوقات تحقيق الجودة في كلية التربية جامعة المنوفية، ورقة عمل مقدمة للندوة العلمية الثانية

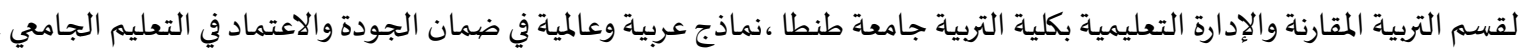

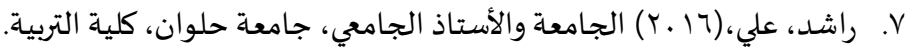

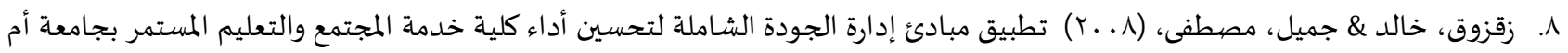
القري ، رسالة ماجستير غير منشورة ، جامعة أم القري ، كلية التربية .

9.

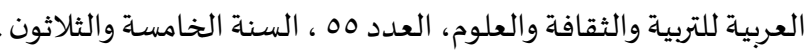

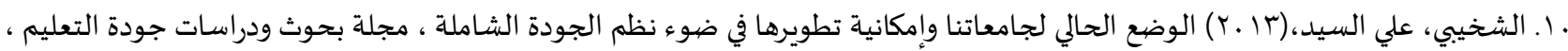

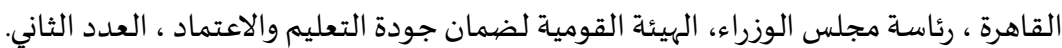

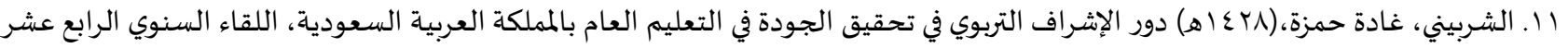

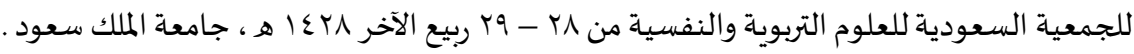

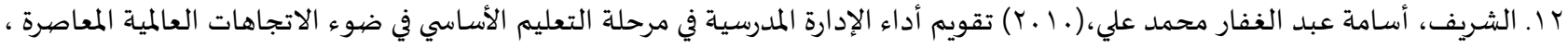

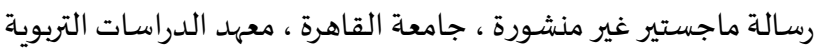

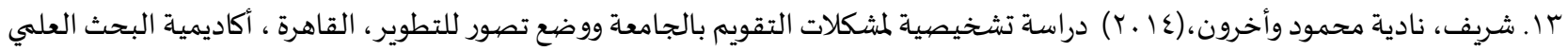
ع ا. شوقي، هدى حسن،(ه . . ( ) معايير مقترحة لجودة أداء معلم تعليم الكبار في فصول ومراكز محو الأمية في تحقيق الجودة في تعليم الكبار في

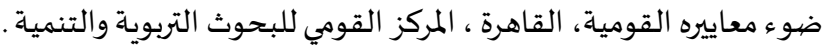

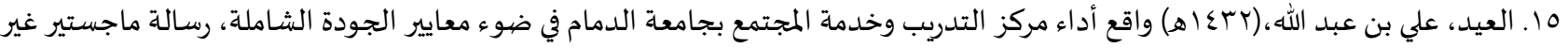
منشورة ، جامعة الملك سعود كلية التربية .

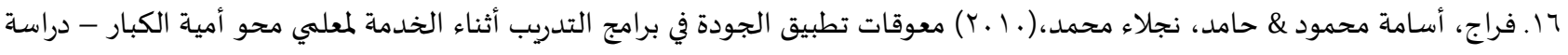

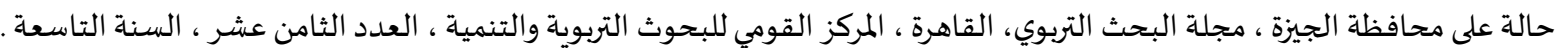

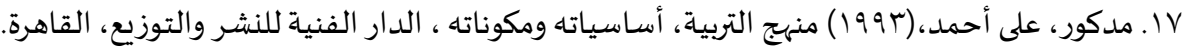

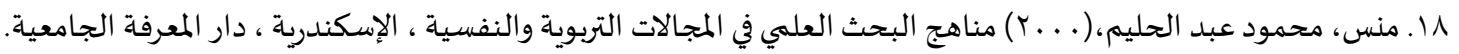

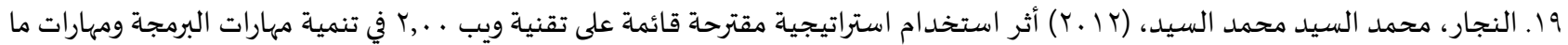

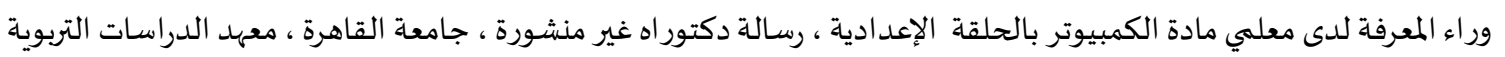

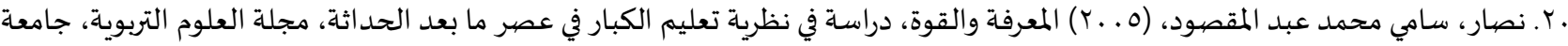

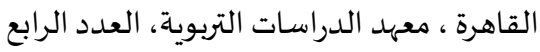
ا r. نوفل، محمد نبيل،(7 . . Y) الجامعة والمجتمع في القرن الحادي والعشرين ، من كتاب المرجع في التنمية المهنية لأعضاء هيئة التدريس بالجامعة والتعليم العالي، إشراف علي أحمد مدكور ، القاهرة ، جامعة القاهرة ، معهد الدراسات التربوية. .

ثانياً: المراجع الأجنبية:

[1] Digumarti Bhaskara Roa, Strengthening the Role of Teacher in a Changing World, New Delhi, Discovery Publishing House, (2003)

[2] Nenadal. j., Comprehensive Quality Assessment Of Czech Higher Education Institutions, International Journal Of Quality and Service sciences,7(2-3)2015, 138-151, https://doi.org/10.1108/ijqss-03-2015-0037

[3] Tsevi. L., Quality Assurance in Private, Higher Education: The Case Ghana, Dissertation, School Of Education, State University Of New York,(2015). 


\title{
Evaluation Study for the Quality Inner System of Education and Art Faculty in Tabuk University
}

\section{Jamela Hamoud Rashed Al Balawi}

Associate Professor- Department of Education and Psychology- Faculty of Education and Arts- KSA drjamela@gmail.com

\begin{abstract}
Aim of the study: aims of university education, challenges face university education, quality system of education and art faculty in Tabuk University, proposals of the decision makers to modify the track of education in the light of the results of the study.

Results of the study: the institutional ability had the first place while the effective of the learning had the second place. There in statistical significance differences among the three variables of the study (gender, degree, membership of the quality unit), and that means to be aware for everyone in faculty members related of the quality unit. The most important points represents in: the availability of a message documented by the faculty, to link the faculty aims with the university aims, announced and documented vision of the faculty, the most important weakest points represents in the weakness of the awareness plan to raise the community service, the environment improvement, and the participation weakness in human development groups.
\end{abstract}

Keywords: evaluation study, the quality inner system.

\section{References:}

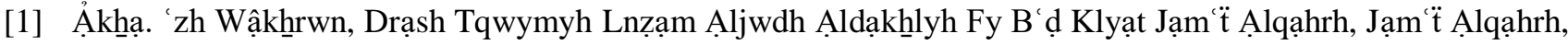
(2010)

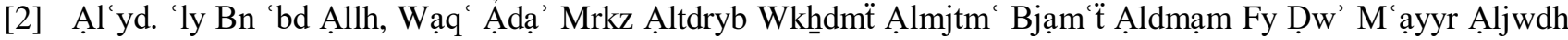

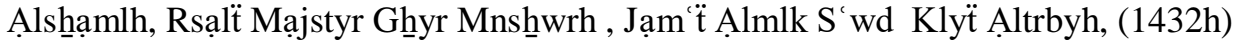

[3] Ạlbnạ. Aymạn Hsn Mhmd 'ly, Tțwyr Aldrạsạt Ạl'lyạa Bklyạt Altrbyë Fy Mșr Fy Dw’ Alm ạyyr Ạlqwmyh Lḍmạn Ạ̉ljwdh Wạlạ tmạd Tṣwr Mqtrḥ, Rsạlẗ Mạjstyr Ghyr Mnshwwrh, Jạm ẗ Bnhạ, Klÿ̈ Ạltrbyh, (2018)

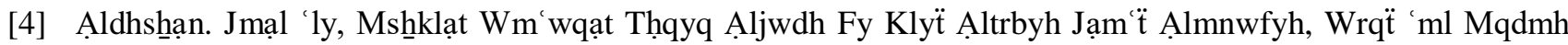

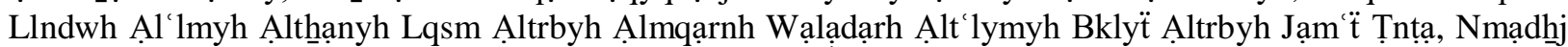
'rbyh W'ạlmyh Fy Ḍmạn Ạljwdh Wạlạ tmạd Fy Ạlt' lym Ạ̉ljạm'y , (1431h)

[5] Ạlnjạr. Mḥmd Ạlsyd Mḥmd Ạlsyd, Ạ̉tḥr Ạstkḥdạm Ạstrạtyjyh Mqtrḥh Qậmh 'la Tqnÿ̈ Wyb 2,00 Fy Tnmÿ̈

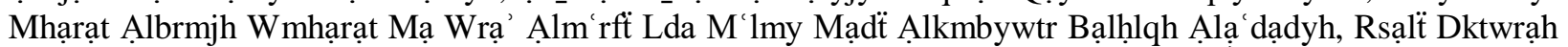
Ghyr Mnshwwrh, Jạm ‘̈ Ạlqạhrh, M’hd Ạldrạsạt Ạltrbwyh, (2012)

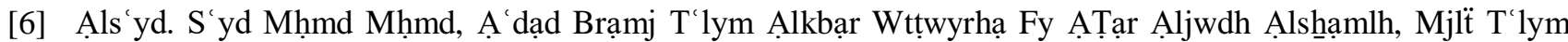

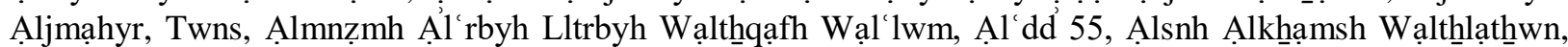
(2008) 
[7] Ạlsh̆khyby. 'ly Ạlsyd, Ạlwḍ' Ạlhạly Ljạm ạtnạ Wạkkạnyh Tțwyrhạ Fy Ḍw' Nẓm Ạljwdh Ạlshạmlh , Mjlï Bḥwth Wdrạsạt Jwd̈̈ Ạlt'lym, Ạlqạhrh, Rỷạsẗ Mjls Ạlwzrạ’, Ạlhyỷh Ạlqwmyh Lḍạn Jwdẗ Ạlt'lym Wạlạ tmạd, Ạl dd Ạlthạny, (2013)

[8] Ạlshrbyny. Ghạdh Ḥmzh, Dwr ẠlạShrạf Ạltrbwy Fy Tḥqyq Aljwdh Fy Ạlt'lym Ạl'ạm Bạlmmlkh Ạl'rbyh

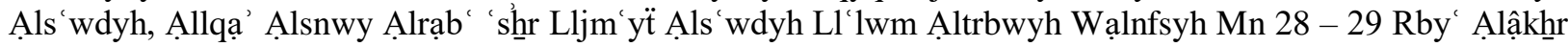
1428 H , Jạm $\mathfrak{t}$ Ạlmlk S’wd, (1428h)

[9] Ạlshryf. Ạ̉sạmë 'bd Ạlgḥfạr Mḥmd 'ly, Tqwym Ạ̉dạ’ Ạlạdạrh Ạlmdrsyh Fy Mrḥlt Ạlt lym Ạlạ̉sạsy Fy Dww'

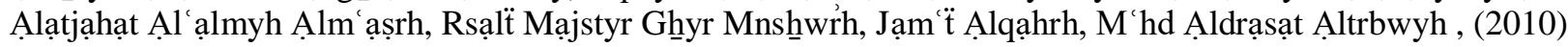

[10] Bdrạn. Sḥbl \& Ạldhshạn. Jmạl, Ạltjdyd Fy Ạlt' lym Ạljạm y, Ạlqạhrh, Dạr Qbạ’ Llṭbạ h h, (2003)

[11] Digumarti Bhaskara Roa, Strengthening the Role of Teacher in a Changing World, New Delhi, Discovery Publishing House, (2003)

[12] Frạj. Ạ̉sạmë Mḥmwd \& Hạmd. Njlạ’ Mḥmd, M'wqạt Tṭbyq Aljwdh Fy Brạmj Ạltdryb Ạ̉tḥnạ’ Ạlkhndmh

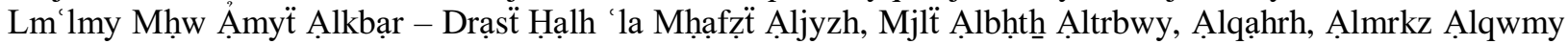
Llbḥwth Ạltrbwyh Wạltnmyh , Ạl'dd Ạlthạmn 'sḥr , Ạlsnh Ạltạs 'h , (2010)

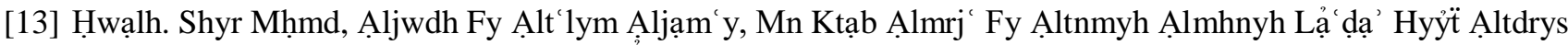

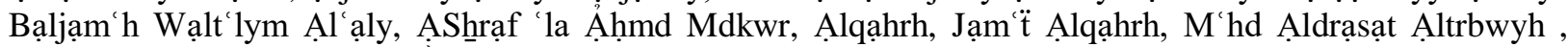
(2006)

[14] Jmạl Ạldyn. Nạdyh, Syạsẗ Ạlqbwl Llt'lym Ạljạm y Fy Ạldwl Ạl'rbyh Wtḥdyạt Ạlạ̉mn Wạlbqạ’,Ạlmw̉tmr Ạltrbwy Ạlthạny: Alt 'lym Ạljạm y Ạl'rby Wtḥdyạt Mṭl' Ạlqrn Ạlhạdy Wạl 'sh̆ryn, 17-20ạ̉bryl 1994m , Jạm ‘̈ 'yn Shms , Klÿ̈ Ạltrby, (1994)

[15] Mdkwr. 'ly Ạ̉ḥmd, Mnhj Ạltrbyh, Ạ̉sạsyạth Wmkwnạth , Ạldạr Ạlfnyh Llnsḥr Wạltwzy', Ạlqạhrh, (1993)

[16] Mns. Mḥmwd 'bd Ạlḥ̣lym, Mnạhj Ạlbḥth Ạl' lmy Fy Ạlmjạlạt Ạltrbwyh Wạlnfsyh, Ạlạiskndryh, Dạr Ạlm rfh Ạljạm yh, (2000)

[17] Nenadal. j., Comprehensive Quality Assessment Of Czech Higher Education Institutions, International Journal Of Quality and Service sciences,7(2-3)2015, 138-151, https://doi.org/10.1108/ijqss-03-2015-0037

[18] Nșạr. Sạmy Mḥmd 'bd Ạlmqșwd, Alm'rfh Wạlqwh, Drạsh Fy Nzryä T'lym Ạlkbạr Fy 'ṣr Mạ B'd Ạlhuạtḥh, Mjlẗ Ạl' lwm Ạltrbwyh, Jạm'‘̈ Ạlqạhrh , M'hd Ạldrạsạt Ạltrbwyh, Ạl'dd Ạlrạb', (2005)

[19] Nwfl. Mḥmd Nbyl, Ạljạm'h Wạlmjtm` Fy Ạlqrn Ạlhạdy Wạl'sh̆hryn, Mn Ktạb Ạlmrj' Fy Ạltnmyh Ạlmhnyh

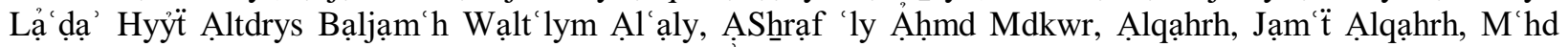
Ạldrạsạt Ạltrbwyh, (2006)

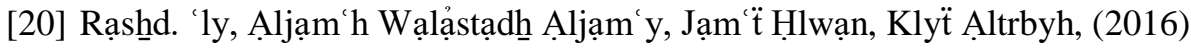

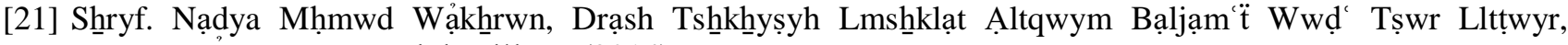
Ạlqạhrh , Ạkạdymyh Ạlbḥth A. Álmy, (2014)

[22] Shnwqy. Hdy Ḥsn, M'ạyyr Mqtrḥh Ljwdể Ạ̉dạ’ M'lm T'lym Ạlkbạr Fy Fșwl Wmrạkz Mḥw Ạlạ̉myh Fy Tḥqyq Ạljwdh Fy T'lym Ạlkbạr Fy Dw’ M'ạyyrh Ạlqwmyh, Ạlqạhrh, Ạlmrkz Ạlqwmy Llbḥwth Ạltrbwyh Wạltnmyh, (2005)

[23] Tsevi. L., Quality Assurance in Private, Higher Education: The Case Ghana, Dissertation, School Of Education, State University Of New York,(2015).

[24] Zqzwq. Khạald \& Jmyl. Mșṭa, Tṭbyq Mbạdỷ Adạr Ạljwdh Ạlshạmlh Ltḥsyn Ạ̉dạ' Klyë Khndmë Ạlmjtm

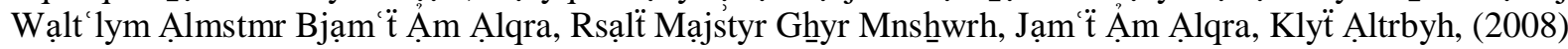

